Check for updates

Cite this: RSC Adv., 2017, 7, 55163

\title{
Naphthoquinone based chemosensors for transition metal ions: experiment and theory $\dagger$
}

\author{
Prajkta Gosavi-Mirkute, (ID $\ddagger^{a}$ Amit Patil, (D) $\ddagger^{a}$ Dipali N. Lande, (D) ${ }^{a}$ \\ Debamitra Chakravarty, (D) ${ }^{b}$ Shridhar P. Gejji, (D) a Surekha Satpute (D) \\ and Sunita Salunke-Gawali (D) *a
}

The synthesis and characterization of 2-((pyridine-2-yl)methylamino)naphthalene-1,4-dione (H-1), 2((thiophen-2-yl)methylamino)naphthalene-1,4-dione ( $\mathrm{H}-2)$ and 2-((pyridine/thiophen-2-yl)ethylamino) naphthalene-1,4-dione $(\mathrm{H}-3$ and $\mathrm{H}-4)$ have been carried out. Molecular recognition abilities of these ligands toward transition metal ions in methanol, methanol-water, methanol-triethylamine or methanol-watertriethylamine mixtures, stoichiometries and association constants of $\mathrm{H}-1$ and $\mathrm{H}-3$ have been determined. It has been shown that $\mathrm{H}-1$ and $\mathrm{H}-3$ coordinate to metal ions via two nitrogen atoms and oxygen and exhibit remarkable selectivity towards $\mathrm{Cu}^{2+}$ ions in methanol or methanol-water mixtures, the complexation being accompanied by a color change from orange to intense blue. LOD (Limit of Detection) of $\mathrm{Cu}^{2+}$ with $\mathrm{H}-1, \mathrm{H}-$ 3 are $1.48 \times 10^{-8} \mathrm{~mol} \mathrm{~L}^{-1}$ and $1.59 \times 10^{-8} \mathrm{~mol} \mathrm{~L}^{-1}$ respectively. The vibrational spectra, ${ }^{1} \mathrm{H}$ NMR chemical shifts and optical properties of $\mathrm{H}-1$ to $\mathrm{H}-4$ derived from density functional theory are also presented.

Received 21st September 2017

Accepted 20th November 2017

DOI: 10.1039/c7ra10490a

rsc.li/rsc-advances

detectable, sensitive signals. A colorimetric and ratiometric

\section{Introduction}

The $\alpha, \beta$-unsaturated carbonyl derivatives of 1,4-naphthoquinones ${ }^{1}$ are of growing interest owing to their anticancer, ${ }^{2-7}$ antimicrobial, ${ }^{8-10}$ antifungal, ${ }^{11-13}$ antitumor ${ }^{14-18}$ and antiviral $^{19-21}$ activities. Their molecular attributes, namely conjugation and electrophilicity, govern metabolic pathways and the key processes in chemotherapy that require redox cycling drugs. ${ }^{22}$ The underlying redox switching of such naphthoquinones, which on the acceptance of one or two electrons yield a radical anion or dianion, are thus interesting. It is further discernible to note that the intra-molecular charge transfer (ICT) transition is shown to be strongly dependent on the amine substituent and in particular, the charge density on the nitrogen center. ${ }^{23}$ These ligands, which serve as chemosensors, have shown remarkable molecular recognition and gave easily

${ }^{a}$ Department of Chemistry, Savitribai Phule Pune University, Pune 411007, India. E-mail: sunitas@chem.unipune.ac.in

${ }^{b}$ Central Instrumentation Facility, Department of Chemistry, Savitribai Phule Pune University, Pune 411007, India

'Department of Microbiology, Savitribai Phule Pune University, Pune 411007, India $\dagger$ Electronic supplementary information (ESI) available: FT-IR, ${ }^{1} \mathrm{H}$ and ${ }^{13} \mathrm{C}$ NMR, DSC are presented in Fig. S1 through Fig. S6. crystallography figures Fig. S7 and S8. Metal ion binding studies on $\mathbf{H - 3}$. Job plot for H-1 Fig. S10 through Fig. S12. Binding constant for H-1 Fig. S13. Job plot for H-3 Fig. S14 through Fig. S16. Binding constant for H-1 Fig. S17. Competative metal ion binding studies for H-3, Fig. S18 through Fig. S19. pH dependent binding (Fig. S20). Limit of detetion (LOD) in Fig. S21 and S22. Crystallographic Tables S1-S12. CCDC 1506931, 1575689 and 1506932 for H-1, H-3 and H-4 respectively. For ESI and crystallographic data in CIF or other electronic format see DOI: 10.1039/c7ra10490a

\$ Contributed equally. fluorescent chemosensor combined with attributes such as high fluorescence sensitivity and aesthetic appeal of colorimetric assay makes these napthoquinone sensors very fascinating. ${ }^{24}$

Naphthoquinone based chemosensors viz., 2-((pyridin-2-yl) methylamino)naphthalene-1,4-dione (H-1), 2-((thiophen-2-yl) methylamino)naphthalene-1,4-dione (H-2) 2-((pyridine/ thiophen-2-yl)ethylamino)naphthalene-1,4-dione (H-3 and $\mathbf{H}-\mathbf{4})$ (Fig. 1) are synthesized and characterized using FT-IR, ${ }^{1} \mathrm{H}$ and ${ }^{13} \mathrm{C}$ NMR and single-crystal X-ray diffraction studies. The chemosensing ability of ligands with metal ions; $\mathrm{La}^{3+}, \mathrm{Hg}^{2+}, \mathrm{Cd}^{2+}$, $\mathrm{Zn}^{2+}, \mathrm{Cu}^{2+}, \mathrm{Cu}^{+}, \mathrm{Ni}^{2+}, \mathrm{Co}^{2+}, \mathrm{Mn}^{2+}, \mathrm{Cr}^{3+}$ and $\mathrm{Ca}^{2+}$ in methanol, methanol-water mixture and in the presence of a mild base such as triethylamine has been evaluated. Moreover, the chemosensors $\mathbf{H}-\mathbf{1}$ and $\mathbf{H}-\mathbf{3}$ are shown to be useful for detection of different metal ions viz., $\mathrm{Cu}^{2+}, \mathrm{Ni}^{2+}$ and $\mathrm{Co}^{2+}$ revealing a color change that can be observed with the naked eye and further can be studied through the UV-visible and fluorescence experiments.

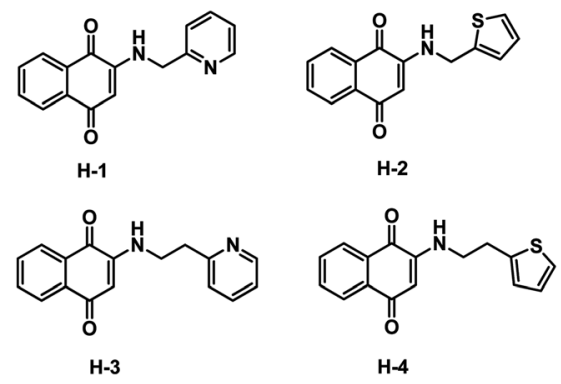

Fig. 1 Molecular structure of $\mathrm{H}-1, \mathrm{H}-2, \mathrm{H}-3$ and $\mathrm{H}-4$. 
On the other hand, $\mathbf{H - 2}$ and $\mathbf{H - 4}$ do not show any chemosensing ability toward the metal ions studied herein.

\section{Experimental}

\section{Materials and methods}

1,4-napthoquinone, 2-methoxy-1,4-napthoquinone, 2-picolyl amine, 2-thiophenemethylamine, 2-(2'-aminoethyl)pyridine, 2- thiopheneethylamine from Sigma-Aldrich; $\mathrm{CuCl}_{2} \cdot 2 \mathrm{H}_{2} \mathrm{O}, \mathrm{CuCl}$, $\mathrm{NiCl}_{2} \cdot 6 \mathrm{H}_{2} \mathrm{O}, \mathrm{ZnCl}_{2}, \mathrm{HgCl}_{2}, \mathrm{CoCl}_{2}, \mathrm{CaCl}_{2}$, triethylamine, methanol and dichloromethane from Merck chemicals; $\mathrm{FeCl}_{3} \cdot 6 \mathrm{H}_{2} \mathrm{O}$ from Qualigens Chemicals, $\mathrm{CrCl}_{3} \cdot 6 \mathrm{H}_{2} \mathrm{O}, \mathrm{CdSO}_{4}, \mathrm{MnCl}_{2} \cdot 4 \mathrm{H}_{2} \mathrm{O}$ from Fluka; $\mathrm{LaCl}_{3} \cdot 7 \mathrm{H}_{2} \mathrm{O}$ from Thomas and Baker were obtained. MilliQ water was used for preparation of aqueous solutions. Anhydrous methanol was prepared by literature reported procedure. ${ }^{25}$ FT-IR spectra (Fig. S1 in ESI $\dagger$ ) were recorded between 4000 and

\section{$\mathrm{H}-1$}

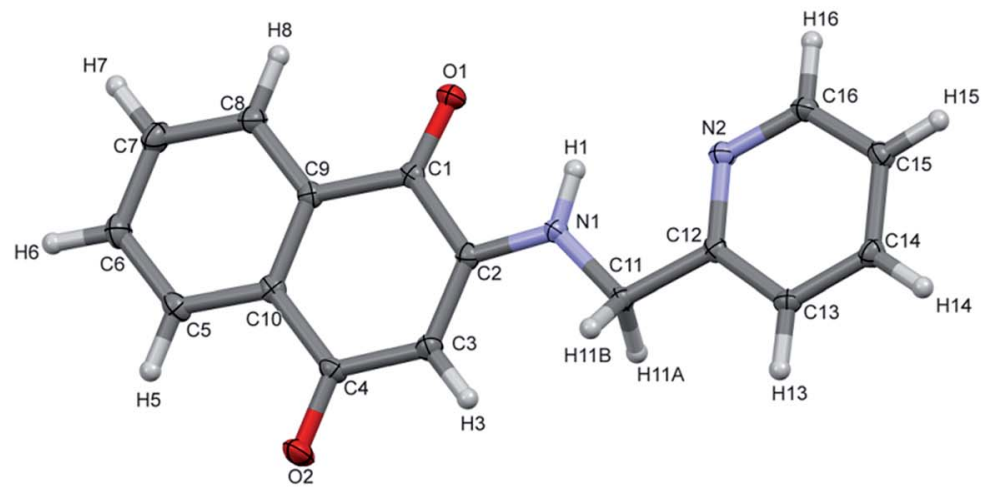

$\mathrm{H}-3$

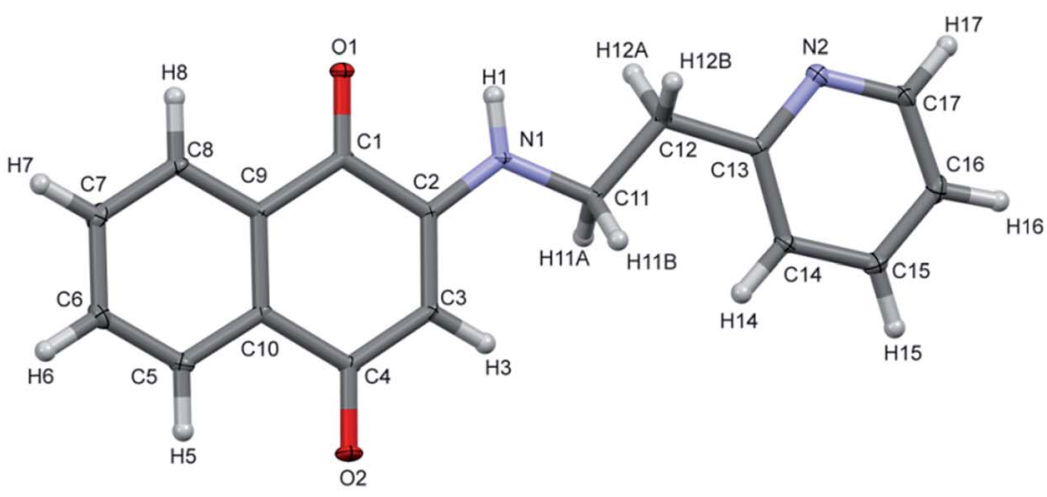

$\mathrm{H}-4$

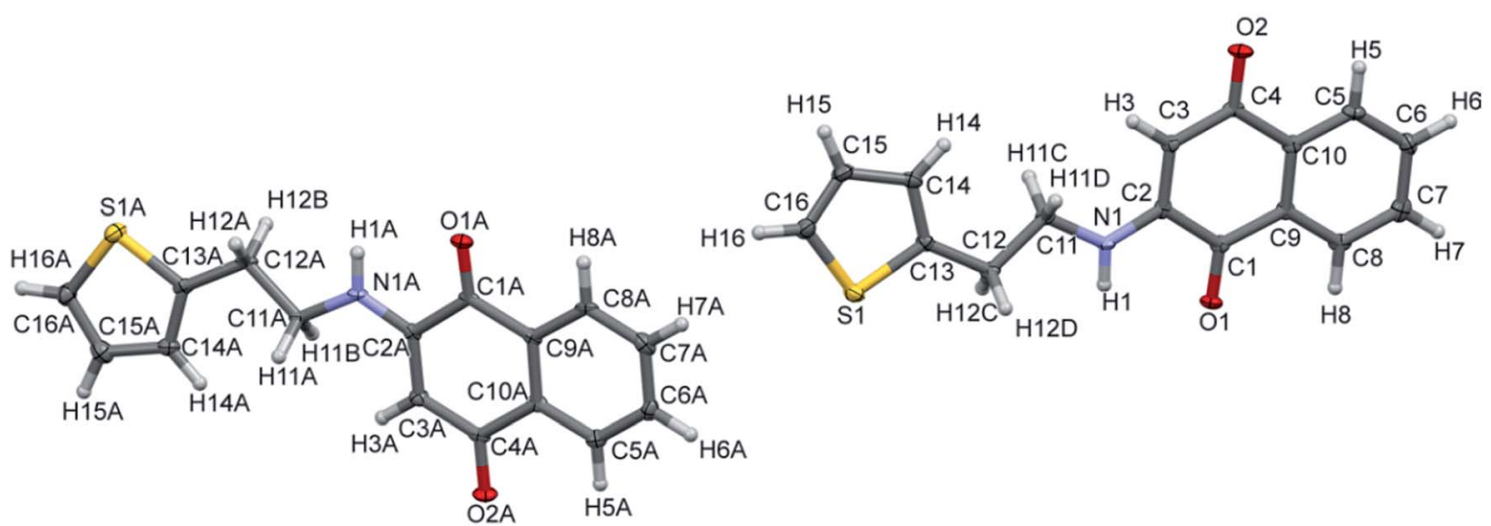

Fig. 2 ORTEP of $\mathrm{H}-1, \mathrm{H}-2, \mathrm{H}-3$ and $\mathrm{H}-4$. The ellipsoid was drawn with $50 \%$ probabilities. 
$400 \mathrm{~cm}^{-1}$ as $\mathrm{KBr}$ pellets on SHIMADZU FT 8400 and Bruker FT-IR Spectrophotometers. The elemental analysis was performed on Thermo Finnigan EA 1112 Flash series Elemental Analyzer. ${ }^{1} \mathrm{H}$ and ${ }^{13} \mathrm{C}$ NMR (Fig. S2-S5 in ESI $\dagger$ ) were obtained in DMSO- $d_{6}$, with the help of Varian Mercury NMR spectrometer using the TMS (tetramethylsilane) as a reference. UV-vis spectra were measured on the SHIMADZU UV 1650 in DMSO between $200 \mathrm{~nm}$ to $800 \mathrm{~nm}$. The fluorescence spectra were recorded on JASCO spectrofluorometer FP-8300. Melting points were observed using the DSC experiments on TA waters model Q2000 instrument (Fig. S6 in ESI $\dagger$ ) equipped with Tzero aluminium pan as a sample holder.

Synthesis of 2-((pyridin-2-yl)methylamino)naphthalene-1,4dione (H-1). $1 \mathrm{mmol}$ of 2-methoxy-1,4-naphthoquinone (0.2 g) was dissolved in $20 \mathrm{ml}$ dry methanol and dichloromethane (5 $\mathrm{ml})$. The solution was stirred for 20 minutes at room temperature $\left(26^{\circ} \mathrm{C}\right)$. To this solution $0.11 \mathrm{ml}$ of 2-picolyl amine $(1 \mathrm{mmol})$ was added drop wise with constant magnetic stirring. The reaction mixture was stirred for 24 hours at room temperature $\left(26{ }^{\circ} \mathrm{C}\right)$ and further refluxed for 2 days at $60{ }^{\circ} \mathrm{C}$. Completion of the reaction was monitored on TLC (toluene : methanol) with a color change from yellow to orange. The mixture after refluxing was further kept for 24 hours for evaporation of solvent which yield the red colored crystals.

Synthesis of 2-((thiophen-2-yl)methylamino)naphthalene1,4-dione (H-2). $1 \mathrm{~g}$ of 1,4-naphthoquinone (6.32 $\mathrm{mmol})$ was taken in two necked round bottom flask. About $20 \mathrm{ml}$ dry methanol was added to just dissolve it. The solution was stirred for $15 \mathrm{~min}$ on a magnetic stirrer. To this solution $0.64 \mathrm{ml}(6.4 \mathrm{mmol})$ of 2-thiophenemethylamine was added drop wise. The reaction mixture was stirred for 24 hours at room temperature $\left(26^{\circ} \mathrm{C}\right)$ with a constant magnetic stirring and the completion of the reaction was monitored on TLC. After 24 hours the mixture was transferred to a beaker and kept for 24 to 48 hours so that the solvent evaporates. A solid crude product was obtained by evaporation was purified by column chromatography with toluene: methanol $(9: 1)$ as eluent. A red colored product was obtained subsequent to a slow evaporation of eluent.

Synthesis of 2-((pyridine/thiophen-2-yl)ethylamino) naphthalene-1,4-dione (H-3 and $\mathbf{H}-4) .1 \mathrm{~g}$ of 1,4-naphthoquinone

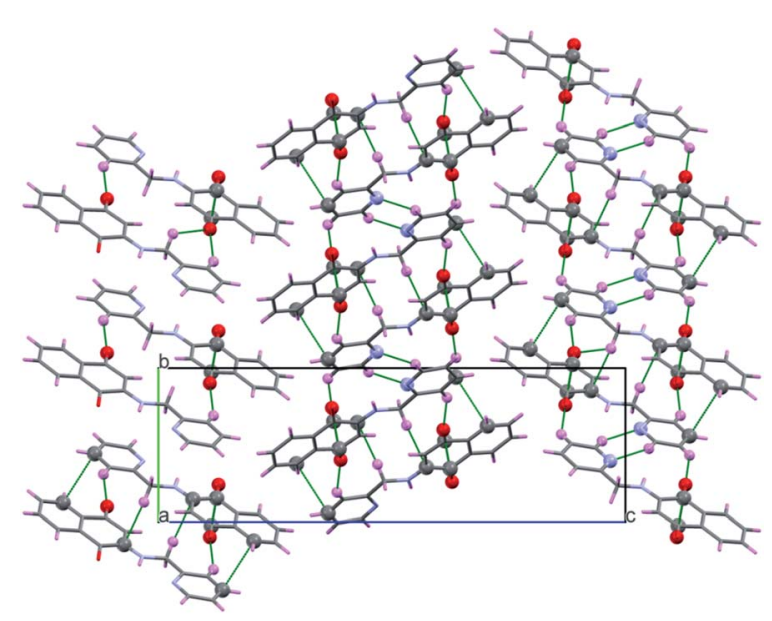

Fig. 3 Polymeric chains of $\mathrm{H}-1$ molecules down a-axis.

Table 1 Single crystal $\mathrm{X}$-ray data for $\mathrm{H}-1, \mathrm{H}-3$ and $\mathrm{H}-4$

Identification code Empirical formula Formula weight Temperature Wavelength Crystal system Space group Unit cell dimensions

Volume

Z

Density (calculated) Absorption coefficient $F(000)$ Crystal size Theta range for data collection Index ranges

Reflections collected Independent reflections

Completeness to theta $=25.242^{\circ}$

Refinement method

Data/restraints/parameters

Goodness-of-fit on $F^{2}$

Final $R$ indices $[I>2 \operatorname{sigma}(I)]$

$R$ Indices (all data)

Extinction coefficient

Largest diff. peak and hole

$\mathrm{H}-1$
$\mathrm{C}_{16} \mathrm{H}_{12} \mathrm{~N}_{2} \mathrm{O}_{2}$
264.28
$100(2) \mathrm{K}$
$0.71073 \AA$
Monoclinic
$P 2_{1} / n$
$a=5.7063(4) \AA$
$b=8.4245(6) \AA, \beta=93.229(2)^{\circ}$
$c=25.6881(19) \AA$
$1232.94(15) \AA^{3}$
4
$1.424 \mathrm{Mg} \mathrm{m}^{-3}$
$0.096 \mathrm{~mm}^{-1}$
552
$0.34 \times 0.26 \times 0.24 \mathrm{~mm}^{3}$
2.893 to $28.388^{\circ}$
$-7<=h<=7,-11<=k<=11$,
$-34<=l<=34$
48104
$3076[R($ int $)=0.0306]$
$99.90 \%$
Full-matrix least-squares on $F^{2}$
$3076 / 0 / 181$
1.032
$R_{1}=0.0393, \mathrm{w} R_{2}=0.1039$
$R_{1}=0.0445, \mathrm{w} R_{2}=0.1079$
$\mathrm{n} / \mathrm{a}$
0.344 and -0.273 e $\AA^{-3}$

H-3

$\mathrm{C}_{17} \mathrm{H}_{14} \mathrm{~N}_{2} \mathrm{O}_{2}$

278.3

$100(2) \mathrm{K}$

$0.71073 \AA$

Monoclinic

$P 2_{1} / n$

$a=5.4000(4) \AA$

$b=30.026(2) \AA, \beta=99.278(2)^{\circ}$

$c=8.0578(6) \AA$

$1289.39(17) \AA^{3}$

4

$1.434 \mathrm{Mg} \mathrm{m}^{-3}$

$0.096 \mathrm{~mm}^{-1}$

584

$13.000 \times 0.210 \times 0.070 \mathrm{~mm}^{3}$

2.713 to $28.345^{\circ}$

$-7<=h<=7,-40<=k<=40$,

$-10<=l<=10$

51719

$3213[R($ int $)=0.0643]$

$99.90 \%$

Full-matrix least-squares on $F^{2}$

$3213 / 0 / 191$

1.054

$R_{1}=0.0610, \mathrm{w} R_{2}=0.1054$

$R_{1}=0.0784, \mathrm{w} R_{2}=0.1114$

$0.0039(6)$

0.440 and -0.361 e $\AA^{-3}$ 
(6.32 mmol) was dissolved in $25 \mathrm{ml}$ methanol and mixture stirred for about $20 \mathrm{~min}$. To this solution $0.70 \mathrm{ml}$ of 2 -(2'-aminoethyl) pyridine ( $7.1 \mathrm{mmol}$ ) for $\mathbf{H}-3$ and $0.69 \mathrm{ml}$ of 2-thiopheneethylamine (7.1 mmol) for $\mathbf{H}-\mathbf{4}$ were added drop wise. The reaction mixture was stirred for 24 hours at room temperature $\left(26^{\circ} \mathrm{C}\right)$ with constant magnetic stirring till completion of the reaction monitored on TLC. The reaction mixture was evaporated under the reduced pressure. The residue was column chromatographed over silica gel in methanol/toluene $(1: 9)$ solvent system. Red coloured solid products were obtained after evaporation of pure fraction from the column.

\section{Characterization}

2-((Pyridin-2-yl)methylamino)naphthalene-1,4-dione; $\quad$ H-1. Dark red colour crystal. Yield: $0.174 \mathrm{~g}$ (62.14\%). mp $156.42{ }^{\circ} \mathrm{C}$. Anal. data calcd for $\mathrm{C}_{16} \mathrm{H}_{12} \mathrm{O}_{2} \mathrm{~N}_{2}$ (\%): C, 72.99; H, 4.21; N, 10.64. Found (\%): C, 72.68; H, 4.10; N, 10.32. FT-IR (KBr; $\left.\nu_{\max }\left(\mathrm{cm}^{-1}\right)\right)$ : 3355, 3061, 1672, 1632, 1605, 1593, 1563, 1432, 1373, 1347, 1290, 1214, 1158, 1122, 1091, 1049, 976, 827, 778, 757, 723, 669, 574, 498, 460, 443. ${ }^{1} \mathrm{H}$ NMR (DMSO- $d_{6}, 499.81 \mathrm{MHz}, \delta(\mathrm{ppm})$ ): $4.52\left(\mathrm{~d}, J=6 \mathrm{~Hz}, 2 \mathrm{H},-\mathrm{CH}_{2}\right), 5.59(\mathrm{~s}, 1 \mathrm{H}, \mathrm{Ar}-\mathrm{CH}), 7.30(\mathrm{t}, J=5 \mathrm{~Hz}$, $1 \mathrm{H}, \mathrm{Ar}), 7.37$ (d, $J=8 \mathrm{~Hz}, 1 \mathrm{H}, \mathrm{Ar}), 7.73$ (t, $J=8 \mathrm{~Hz}, 1 \mathrm{H}, \mathrm{Ar}), 7.77$ $(\mathrm{m}, J=8 \mathrm{~Hz}, 1 \mathrm{H}, \mathrm{Ar}), 7.81(\mathrm{~m}, J=7.5 \mathrm{~Hz}, 1 \mathrm{H}, \mathrm{Ar}), 7.90$ (d, $J=$ $8 \mathrm{~Hz}, 1 \mathrm{H}, \mathrm{Ar}), 8.00$ (d, $J=8 \mathrm{~Hz}, 1 \mathrm{H}, \mathrm{Ar}), 8.08$ (t, $J=6.5 \mathrm{~Hz}, 1 \mathrm{H}$, $-\mathrm{NH}$ ), 8.55 (d, $J=5 \mathrm{~Hz}, 1 \mathrm{H}, \mathrm{Ar}$ ). ${ }^{13} \mathrm{C}$ NMR (DMSO- $d_{6}, 125.69$ $\mathrm{MHz}, \delta$ (ppm)): 47.40, 101.09, 121.98, 123.00, 125.82, 126.39, 130.86, 132.77, 133.47, 135.32, 137.47, 148.87, 149.49, 156.80, 181.95. UV-vis, $\left(\lambda_{\max }\right.$, methanol $\left.(\mathrm{nm})\right): 440$.

2-((Thiophen-2-yl)methylamino)naphthalene-1,4-dione; H-2. Brown colored solid. Yield: $0.962 \mathrm{~g}$ (89.90\%). mp $189.73{ }^{\circ} \mathrm{C}$. Anal. data calcd for $\mathrm{C}_{15} \mathrm{H}_{11} \mathrm{O}_{2} \mathrm{NS}$ (\%): C, 66.89; H, 4.11; N, 5.20; S, 11.90. Found (\%) C, 66.44; H, 3.84; N, 5.16; S, 11.65. FT-IR $\left(\mathrm{KBr} ; \nu_{\max }\left(\mathrm{cm}^{-1}\right)\right): 3354,1670,1599,1506,1453,1429,1306$, 1252, 1216, 1147, 1056, 1025, 835, 778, 708, 687, 627, 557, 542, 493, 444. ${ }^{1} \mathrm{H}$ NMR (DMSO- $\left.d_{6}, 499.81 \mathrm{MHz}, \delta(\mathrm{ppm})\right): 4.16(\mathrm{~s}, 2 \mathrm{H}$, $\left.-\mathrm{CH}_{2}\right), 5.74(\mathrm{~s}, 1 \mathrm{H}, \mathrm{Ar}-\mathrm{CH}), 6.97(\mathrm{t}, J=4.5 \mathrm{~Hz}, 1 \mathrm{H}, \mathrm{Ar}), 7.10(\mathrm{~d}, J$ $=2.5 \mathrm{~Hz}, 1 \mathrm{H}, \mathrm{Ar}), 7.40(\mathrm{~d}, J=4.5 \mathrm{~Hz}, 1 \mathrm{H}, \mathrm{Ar}), 7.71(\mathrm{t}, J=7.5 \mathrm{~Hz}$, $1 \mathrm{H}, \mathrm{Ar}), 7.80$ (t, J=7 Hz, 1H, Ar), 7.90 (d, J=7.5 Hz, 1H, Ar), 7.97 (d, $J=7.5 \mathrm{~Hz}, 1 \mathrm{H}, \mathrm{Ar}), 8.11(\mathrm{t}, J=6.5,1 \mathrm{H},-\mathrm{NH}) .{ }^{13} \mathrm{C} \mathrm{NMR}$ (DMSO- $d_{6}, 125.69 \mathrm{MHz}, \delta(\mathrm{ppm})$ ): 40.42, 100.67, 125.31, 125.33, 125.86, 126.10, 126.75, 130.32, 132.27, 132.87, 134.82, 140.38, 148.00, 181.48, 181.53. UV-vis, ( $\lambda_{\max }$, methanol (nm)): 435.

2-((Pyridin-2-yl)ethylamino)naphthalene-1,4-dione; H-3. Dark red color crystal. Yield: $1.126 \mathrm{~g}$ (64.01\%). mp. $128.58{ }^{\circ} \mathrm{C}$. Anal. data calcd for $\mathrm{C}_{17} \mathrm{H}_{14} \mathrm{O}_{2} \mathrm{~N}_{2}$ (\%): C, 73.36; $\mathrm{H}, 5.07 ; \mathrm{N}, 11.49$. Found (\%): C, 72.98; H, 5.10; N, 11.36. FT-IR (KBr, $\left.\nu_{\max }\left(\mathrm{cm}^{-1}\right)\right)$ : 3336, 3043, 2960, 2914, 2868, 1772, 1672, 1600, 1570, 1518, 1467, 1435, 1356, 1284, 1261, 1215, 1155, 1103, 1057, 1022, 983, 862, 785, 721, 669, 596, 559, 507, 476. ${ }^{1} \mathrm{H}$ NMR (DMSO- $d_{6}, 499.81$ $\mathrm{MHz}, \delta(\mathrm{ppm})): 3.04\left(\mathrm{t}, J=5 \mathrm{~Hz}, 2 \mathrm{H},-\mathrm{CH}_{2}\right), 3.54(\mathrm{t}, J=5 \mathrm{~Hz}, 2 \mathrm{H}$, $\left.-\mathrm{CH}_{2}\right), 5.71$ (s, 1H, Ar), 7.23 (t, $\left.J=5 \mathrm{~Hz}, 1 \mathrm{H}, \mathrm{Ar}\right), 7.32(\mathrm{~d}, J=5 \mathrm{~Hz}$, $1 \mathrm{H}, \mathrm{Ar}), 7.62(\mathrm{t}, J=5 \mathrm{~Hz}, 1 \mathrm{H},-\mathrm{NH}), 7.705(\mathrm{t}, J=5 \mathrm{~Hz}, 1 \mathrm{H}, \mathrm{Ar})$, $7.72(\mathrm{t}, J=5 \mathrm{~Hz}, 1 \mathrm{H}, \mathrm{Ar}), 7.81(\mathrm{t}, J=10 \mathrm{~Hz}, 1 \mathrm{H}, \mathrm{Ar}), 7.92(\mathrm{~d}, J=$ $5 \mathrm{~Hz}, 1 \mathrm{H}, \mathrm{Ar}), 7.95$ (d, $J=10 \mathrm{~Hz}, 1 \mathrm{H}, \mathrm{Ar}), 8.51$ (d, $J=5 \mathrm{~Hz}, 1 \mathrm{H}$, Ar). ${ }^{13} \mathrm{C}$ NMR (DMSO- $d_{6}, 125.69 \mathrm{MHz}, \delta(\mathrm{ppm})$ ): 35.34, 41.61, $99.51,121.69,123.35,125.31,125.85,130.32,132.14,133.10$,
134.82, 136.61, 148.28, 149.07, 158.66, 181.26, 181.46. UV-vis, $\left(\lambda_{\max }\right.$, methanol $\left.(\mathrm{nm})\right): 448$.

2-((Thiophen-2-yl)ethylamine)naphthalene-1,4-dione; H-4. Dark red color crystals. Yield: $1.08 \mathrm{~g}$ (60.33\%). mp. $145.5{ }^{\circ} \mathrm{C}$. Anal. data calcd for $\mathrm{C}_{16} \mathrm{H}_{13} \mathrm{O}_{2} \mathrm{NS}(\%)$ : C, 67.82; H, 4.62; N, 4.94; S, 11.31. Found (\%): C, 67.58; H, 4.36; N, 5.02; S, 11.67. FT-IR $\left(\mathrm{KBr}, \nu_{\max }\left(\mathrm{cm}^{-1}\right)\right): 3338,3043,2915,1669,1515,1593,1567$, 1514, 1465, 1434, 1395, 1353, 1336, 1298, 1278, 1242, 1215, 1120, 1098, 1031, 978, 859, 773, 722, 684, 583, 505, 466. ${ }^{1} \mathrm{H}$ NMR (DMSO- $\left.d_{6}, 499.81 \mathrm{MHz}, \delta(\mathrm{ppm})\right): 3.12\left(\mathrm{t}, J=7 \mathrm{~Hz}, 2 \mathrm{H},-\mathrm{CH}_{2}\right)$, $3.45\left(\mathrm{t}, J=6.5 \mathrm{~Hz}, 2 \mathrm{H},-\mathrm{CH}_{2}\right), 5.72(\mathrm{~s}, 1 \mathrm{H}, \mathrm{Ar}), 6.94(\mathrm{~d}, J=3.5 \mathrm{~Hz}$, $1 \mathrm{H}, \mathrm{Ar}), 6.96(\mathrm{t}, J=5 \mathrm{~Hz}, 1 \mathrm{H}, \mathrm{Ar}), 7.33$ (d, J=4.5 Hz, 1H, Ar), 7.55 $(\mathrm{t}, J=6 \mathrm{~Hz}, 1 \mathrm{H},-\mathrm{NH}), 7.72(\mathrm{t}, J=7.5 \mathrm{~Hz}, 1 \mathrm{H}, \mathrm{Ar}), 7.82(\mathrm{t}, J=$ $7.5 \mathrm{~Hz}, 1 \mathrm{H}, \mathrm{Ar}$ ), 7.93 (d, $J=8 \mathrm{~Hz}, 1 \mathrm{H}, \mathrm{Ar}), 7.97$ (d, $J=7.5 \mathrm{~Hz}, 1 \mathrm{H}$, Ar). ${ }^{13} \mathrm{C}$ NMR (DMSO- $d_{6}, 125.69 \mathrm{MHz}, \delta(\mathrm{ppm})$ ): 27.55, 43.31, $99.67,124.27,125.31,125.55,125.87,127.00,130.31,132.17$, 133.07, 148.24, 181.45. UV-vis, ( $\lambda_{\max }$, methanol (nm)): 448.

\section{X-ray crystal structures}

X-ray data for $\mathbf{H - 1}, \mathbf{H}-\mathbf{3}$ and $\mathbf{H}-\mathbf{4}$ were collected on D8 Venture PHOTON 100 CMOS diffractometer using graphite monochromatized Mo-K $\alpha$ radiation $(\lambda=0.7107 \AA)$ with exposure/ frame $=10 \mathrm{~s}$. The X-ray generator was operated at $50 \mathrm{kV}$ and $30 \mathrm{~mA}$. An initial set of cell constants and an orientation matrix were calculated from total 24 frames. The optimized strategy used for data collection included different sets of $\phi$ and $\omega$ scans with $0.5^{\circ}$ steps in $\phi / \omega$. Crystal to detector distance was $5.00 \mathrm{~cm}$ with $512 \times 512$ pixels/frame, oscillation/frame $-0.5^{\circ}$, maximum detector swing angle $=-30.0^{\circ}$, beam centre $=(260.2,252.5)$, in plane spot width $=1.24$. Data integration was carried out by Bruker SAINT program and empirical absorption correction for intensity data were carried out using the Bruker SADABS. The programs are integrated in APEX II package. ${ }^{26}$ The data were corrected for Lorentz and polarization effect. The structure was solved by direct method using the SHELX-97 (ref. 27) with the final refinement of the structure performed by a full-matrix least-squares technique with anisotropic thermal data for non-hydrogen atoms on $F^{2}$. The non-hydrogen atoms were refined anisotropically where the hydrogen atoms were refined at the calculated positions as riding atoms with isotropic displacement parameters. ${ }^{27}$ Molecular diagrams were generated using the ORTEP-3 (ref. 28) and Mercury programs. ${ }^{29}$ Structural calculations were performed using SHELXTL ${ }^{30}$ and PLATON. ${ }^{31}$

\section{Metal ion binding studies, Job plot, competitive binding studies, pH studies and limit of detection (LOD) experiments}

Metal ion binding studies were evaluated by following methods, (i) in methanol, (ii) in 1:1 methanol-water, (iii) in presence of triethylamine in (i) and (ii). In typical experiments $2 \mathrm{ml}$ of $\mathbf{H - 1}$ and $\mathbf{H}-3$ was mixed with $2 \mathrm{ml}$ of metal ion solutions at room temperature $\left(26^{\circ} \mathrm{C}\right) .1 \mathrm{ml}$ of triethylamine was added in chemosensor solution in case of (i) and (ii) prior to addition of metal ion solutions. UV-visible and fluorescence spectra of all solutions were measured; the concentration of $\sim 2.5 \times 10^{-4} \mathrm{M}$ was used.

Micromolar concentration $(10-100 \mu \mathrm{M})$ of $\mathbf{H - 1}, \mathbf{H}-3$ and metal ions was used for Jobs plot experiment. Solutions were prepared 
by varying concentration of ligands and metal ions. Binding constant of $\mathrm{Cu}^{2+}$ and $\mathrm{Ni}^{2+}$ was determined by Stern-Volmer plot. 5 $\times 10^{-4} \mathrm{M}$ solution of chemosensor and $1 \times 10^{-3} \mathrm{M}$ metal ion solutions in methanol were used to obtained the same.

For competitive binding of metal ions $\left(5 \times 10^{-3} \mathrm{M}\right)$ with $\mathbf{H - 1}$ and $\mathbf{H}-3\left(5 \times 10^{-3} \mathrm{M}\right)$ equal volumes were mixed and fluorescence spectra of all solutions were measured.

For quantum yield experiment fluorescien is used as standard. Fluorescien $\left(1 \times 10^{-6} \mathrm{M}\right)$, H-1 and $\mathbf{H}-\mathbf{3}\left(1 \times 10^{-6} \mathrm{M}\right)$ concentration is used. $0.1 \mathrm{M} \mathrm{NaOH}$ was used for the deprotonation of fluorescien.

In $\mathrm{pH}$ dependent metal ion binding studies experiments, $2 \mathrm{ml}$ of chemosensor $\mathbf{H - 1}$ and $\mathbf{H}-\mathbf{3}$ was mixed with $2 \mathrm{ml}$ of metal ion solutions $\left(\mathrm{Cu}^{2+}, \mathrm{Ni}^{2+}, \mathrm{Zn}^{2+}\right.$ and $\left.\mathrm{Co}^{2+}\right)$ at room temperature $\left(26{ }^{\circ} \mathrm{C}\right) .2 \mathrm{ml}$ of buffer solution at $\mathrm{pH} 4$, pH 7 and $\mathrm{pH} 9$ was added respectively prior to addition of metal ion solutions. UVvisible spectra of all solutions were measured.

Micromolar concentrations (10 to $100 \mu \mathrm{M}$ ) of $\mathbf{H}-\mathbf{1}, \mathbf{H}-\mathbf{3}$ and $\mathrm{Cu}^{2+}$ metal ions were used for LOD experiments. Solutions were prepared by varying concentrations of $\mathbf{H}-\mathbf{1}, \mathbf{H}-\mathbf{3}$ and $\mathrm{Cu}^{2+}$ metal ions.

\section{Computational methodology}

Optimizations of naphthoquinone derivatives were carried out using the GAUSSIAN-09 program. ${ }^{32}$ Global hybrid meta GGA
(M06-2X) functional was used in conjuction with the internally stored 6-311++G(d,p) basis set. Stationary point structures thus obtained were confirmed to be the local minima on the potential energy surfaces through vibrational frequency calculations. Frontier orbitals were derived in the same framework of theory. Electronic spectra were computed using the time dependent density functional theory (TD-DFT).

\section{Results and discussion}

\section{Synthesis and characterization of $\mathrm{H}-1, \mathrm{H}-2, \mathrm{H}-3$ and $\mathrm{H}-4$}

Chemosensor $\mathbf{H}-\mathbf{1}, \mathbf{H}-\mathbf{2}, \mathbf{H}-\mathbf{3}$ and $\mathbf{H}-\mathbf{4}$ were synthesized and obtained in high yields at the room temperature $\left(26^{\circ} \mathrm{C}\right)$ without

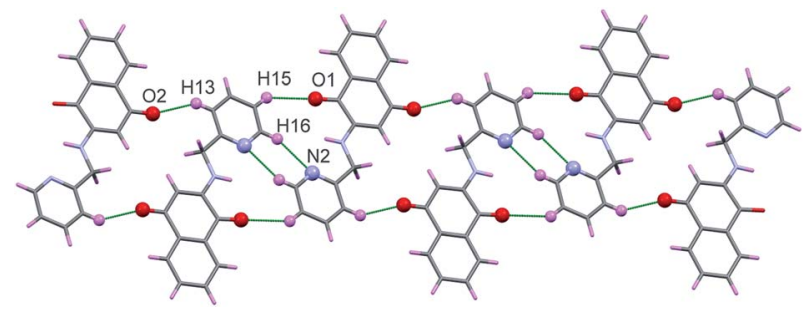

Fig. 4 Polymeric chain of $\mathrm{H}-1$ showing $\mathrm{C}-\mathrm{H} \cdots \mathrm{O}$ and $\mathrm{C}-\mathrm{H} \cdots \mathrm{N}$ interaction.

Table 2 Hydrogen bonding geometries of $\mathrm{H}-1, \mathrm{H}-3$ and $\mathrm{H}-4$

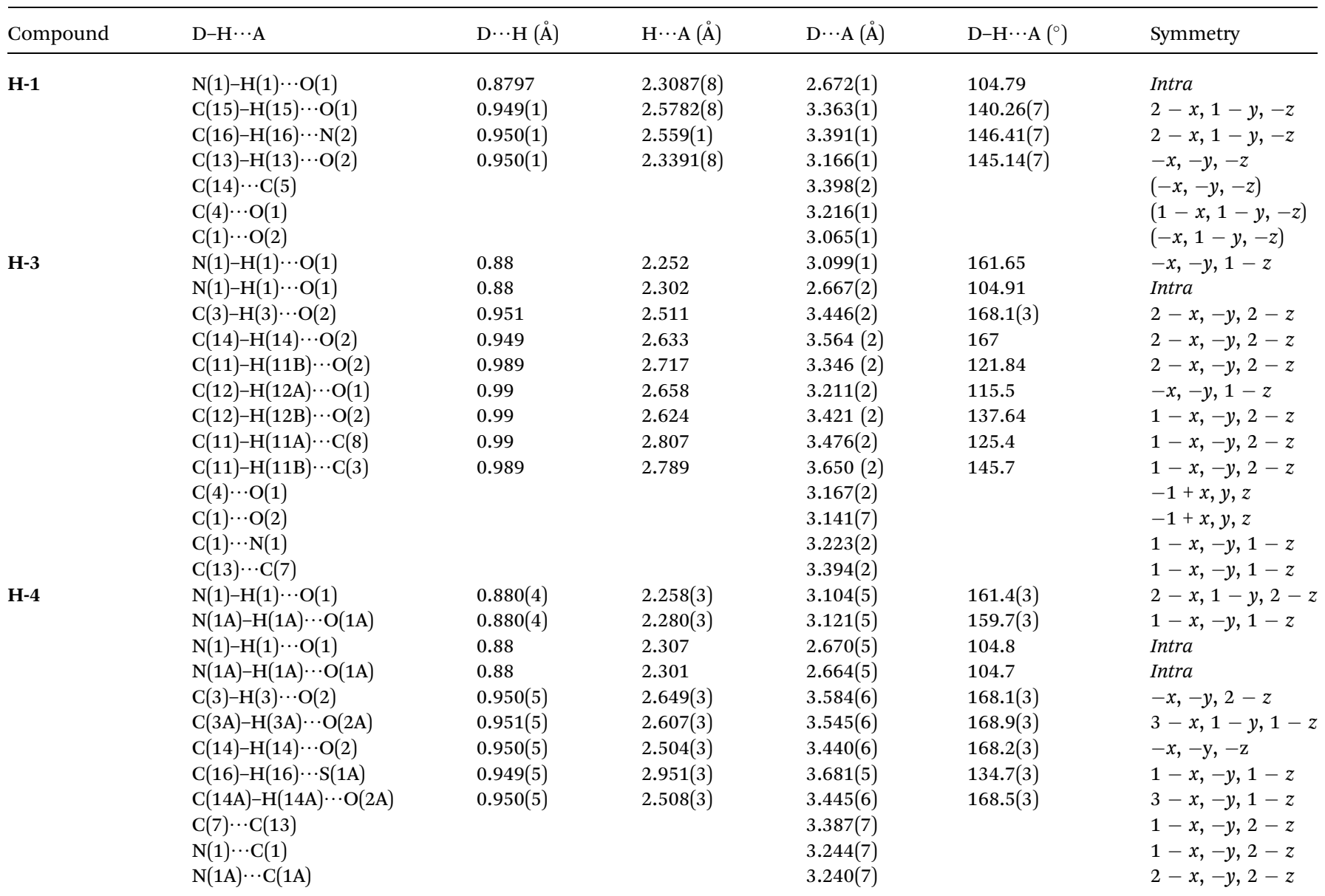


using any exhaustive synthetic procedures. $\mathbf{H}-\mathbf{1}, \mathbf{H}-2, \mathbf{H}-\mathbf{3}$ and $\mathbf{H}-$ 4 were characterized by FT-IR (Fig. S1 ESI $\dagger$ ), ${ }^{1} \mathrm{H}$ and ${ }^{13} \mathrm{C}$ NMR (Fig. S2 through Fig. S5 in ESI†), elemental analysis, UV-visible spectroscopy and single crystal X-ray diffraction studies. Melting point of chemosensor ligands were obtained by Differential Scanning Calorimetry (DSC) (Fig. S6 in ESI†). FT-IR spectra of the ligands reveals characteristic $\mathrm{N}-\mathrm{H}$ stretching observed at the $3355 \mathrm{~cm}^{-1}(\mathbf{H}-\mathbf{1}), 3354 \mathrm{~cm}^{-1}(\mathbf{H}-2), 3336 \mathrm{~cm}^{-1}$ (H-3) and $3338 \mathrm{~cm}^{-1}(\mathbf{H}-4)$. The carbonyl frequency was assigned to the $\sim 1672 \mathrm{~cm}^{-1}$ in $\mathbf{H}-\mathbf{1}$ and $\mathbf{H}-3,1670 \mathrm{~cm}^{-1}$ in $\mathbf{H}-2$

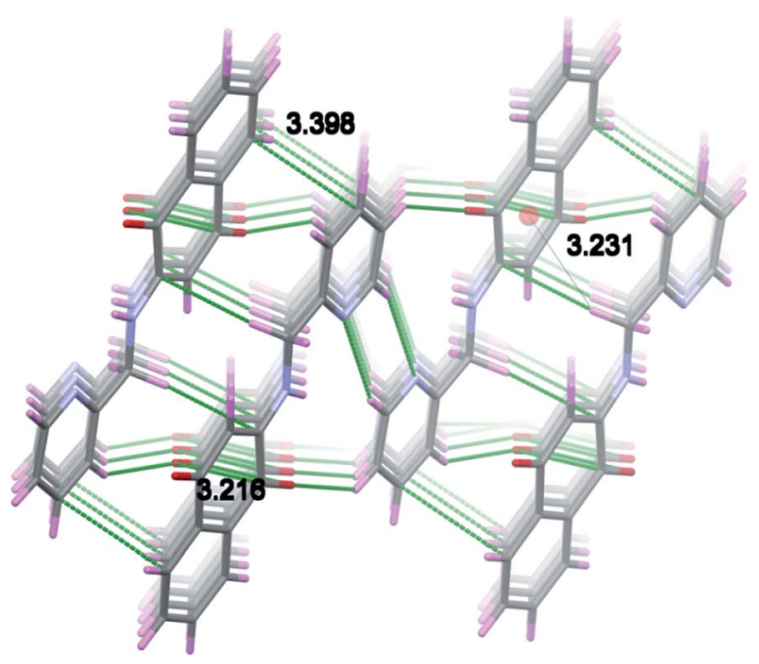

Fig. 5 Figure showing $\pi-\pi$ stacking and $\mathrm{C}-\mathrm{H} \cdots \pi$ interactions to $\mathrm{H}-1$ molecules.

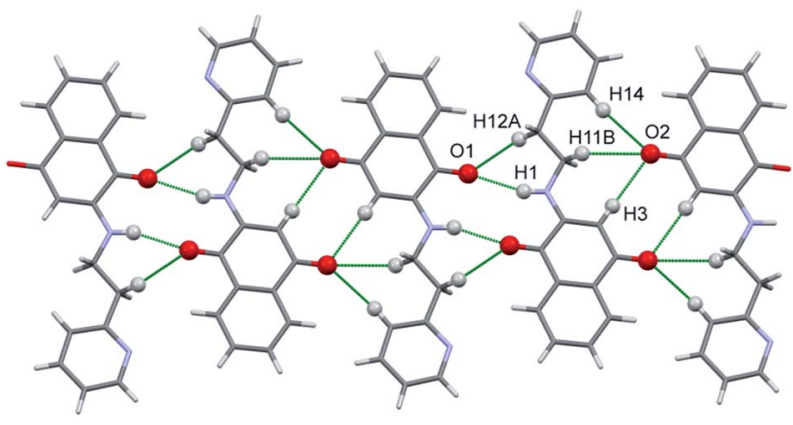

and $\sim 1669 \mathrm{~cm}^{-1}$ in $\mathbf{H}-4$. The $\mathrm{C}-\mathrm{S}$ frequency was observed in the range $\sim 1467 \mathrm{~cm}^{-1}$ (in $\mathbf{H - 3}$ ) to $1432 \mathrm{~cm}^{-1}$ (in $\mathbf{H - 1}$ ).

ORTEP of H-1, H-3 and $\mathbf{H - 4}$ are shown in Fig. 2 and crystallography data have been summarized in Table 1 . H-1 and H-3 shows the monoclinic space group while $\mathbf{H}-4$ shows triclinic space group. The carbonyl bond distances (1.21 $\AA$ and $1.23 \AA$ ) in these compounds resemble to those observed in the oxidized form of compounds. The bond distances represent quinonoid distortion with two short and four long $\mathrm{C}-\mathrm{C}$ bonds. The carbonyl $\mathrm{C}(1)-\mathrm{O}(1)$ and $\mathrm{C}(4)-\mathrm{O}(2)$ bond distances are found to be $1.220 \AA$ and $1.234 \AA$, respectively. The $\mathrm{C}(2)-\mathrm{N}(1)$ bond distances $(1.335 \AA)$ match well with those of amino derivatives of 1,4-naphthoquinone. ${ }^{33-38}$

As may readily be noticed, $\mathbf{H}-\mathbf{1}$ shows naphthoquinone and pyridyl rings to be coplanar (Fig. S7 in ESI $\dagger$ ) in and render interas well as the intra-molecular $\mathrm{N}-\mathrm{H} \cdots \mathrm{O}$ hydrogen bonding which arise from quinonoid oxygen (Table 2).

Two molecules of $\mathbf{H - 1}$ oriented in the opposite directions orientations which facilitate further intermolecular $\mathrm{C}-\mathrm{H} \cdots \mathrm{N}$ $(\mathrm{C}(16)-\mathrm{H}(16) \cdots \mathrm{N}(2))$ and $\mathrm{C}-\mathrm{H} \cdots \mathrm{O}(\mathrm{C}(15)-\mathrm{H}(15) \cdots \mathrm{O}(1))$ hydrogen bonding. Subsequently the dimeric units are linked by the $\mathrm{C}-\mathrm{H} \cdots \mathrm{O}(\mathrm{C}(13)-\mathrm{H}(13) \cdots \mathrm{O}(2))$ interactions along a polymeric chain down $a$-axis ( $c f$. Fig. 3 and 4 ) facilitate $\mathrm{C}-\mathrm{H} \cdots \pi$ interactions between the alkyl proton $\mathrm{C}(11)-\mathrm{H}(11 \mathrm{~B})$ and quinonoid ring; with the corresponding distance being $3.231 \AA$ A. Benzenoid carbon $\mathrm{C}(5)$ in close contact with neighbouring molecules pyridine ring carbon $\mathrm{C}(14)(3.398(2) \AA,(1-x,-y,-z)$ (cf. Fig. 5); the $\mathrm{C}(4) \cdots \mathrm{O}(1)(-1+x, y, z)$ separation of neighbouring molecules was $3.216 \AA$.

The mutual orientation of pyridyl ring with naphthoquinone show a marginal deviation (Fig. S8 in ESI $\dagger$ ) from the planarity as adjudged from the $\mathrm{C}(11)-\mathrm{N}(1)-\mathrm{C}(2)-\mathrm{C}(1)$ dihedral angle parameters. A bidentate coordination of $\mathbf{H}-3$ ligand with the metal ions is favoured; as inferred earlier in ref. 39-41.

As far as $\mathbf{H - 3}$ is concerned the opposite orientation was noticed (with respect pyridine ring) with a polymeric chain therein extending from one end by $\mathrm{N}(1)-\mathrm{H}(1) \cdots \mathrm{O}(1)$ and $\mathrm{C}(12)-$ $\mathrm{H}(12 \mathrm{~A}) \cdots \mathrm{O}(1), \mathrm{C}(3)-\mathrm{H}(3) \cdots \mathrm{O}(2), \mathrm{C}(12)-\mathrm{H}(12 \mathrm{~B}) \cdots \mathrm{O}(2)$ and $\mathrm{C}(14)-$ $\mathrm{H}(14) \cdots \mathrm{O}(2)$ hydrogen bonding interactions, which are depicted in Fig. 6 and 7. Furthermore the polymeric chain brings about $\mathrm{C}-\mathrm{H} \cdots \pi, \quad \mathrm{C} \cdots \mathrm{C}(\mathrm{C}(7) \cdots \mathrm{C}(13)), \quad \mathrm{C} \cdots \mathrm{N} \quad(\mathrm{C}(1) \cdots \mathrm{N}(1))$ and $\mathrm{C} \cdots$ $\mathrm{O}(\mathrm{C}(4) \cdots \mathrm{O}(4))$ stacking interactions as shown in Fig. 8. Besides the $\mathrm{C}-\mathrm{H} \cdots \pi$ interactions from ethyl protons and $\mathrm{C}(11)-(11 \mathrm{~A})$ of

Fig. 6 Polymeric chains of $\mathrm{H}-3$ molecules down a-axis.

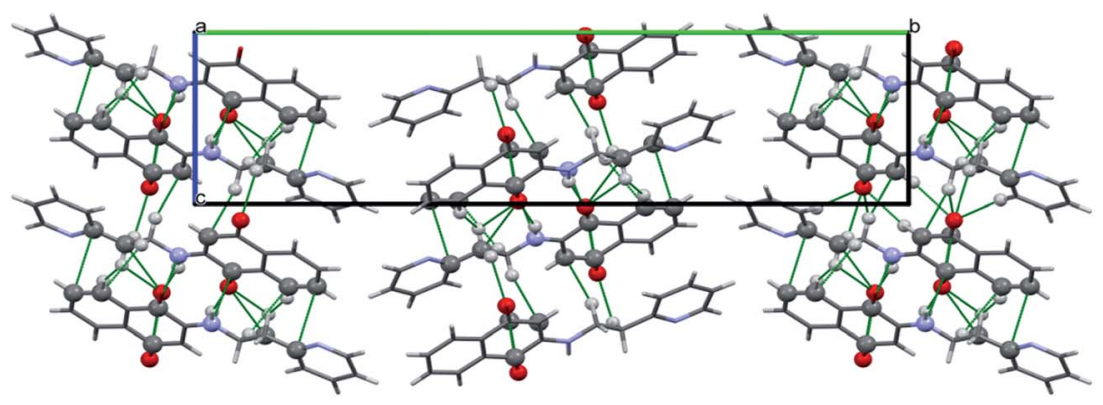

Fig. 7 Polymer chain of $\mathrm{H}-3$ showing $\mathrm{N}-\mathrm{H} \cdots \mathrm{O}$ and $\mathrm{C}-\mathrm{H} \cdots \mathrm{O}$ interaction. 
a)

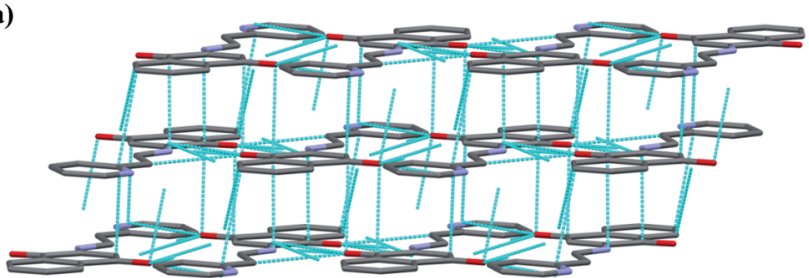

b)

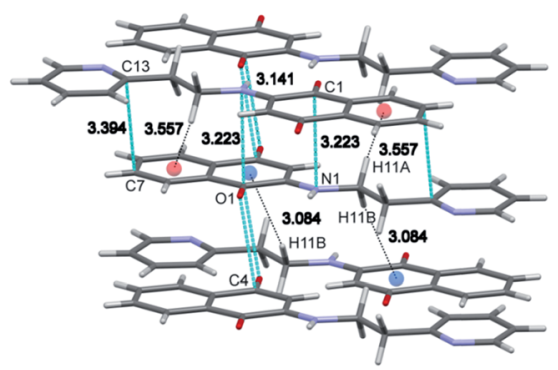

Fig. 8 (a) and (b) showing $\pi-\pi$ stacking and $\mathrm{C}-\mathrm{H} \cdots \pi$ interaction in $\mathrm{H}$ 3 molecule.

the benzenoid ring and those between $\mathrm{C}(12)-\mathrm{H}(12 \mathrm{~B})$ and quinonoid can readily be noticed.

Unlike $\mathbf{H}-\mathbf{1}$ and $\mathbf{H}-\mathbf{3}$ the polymeric chains of $\mathbf{H}-\mathbf{4}$ reveal two asymmetric molecules linked by the $\mathrm{C}(16)-\mathrm{H}(16) \cdots \mathrm{S}(1 \mathrm{~A})(1-x$, $-y, 1-z)$ interactions which are depicted in Fig. 9. In addition to these $\mathrm{C}(11)-\mathrm{H}(11 \mathrm{~A}) \cdots \pi$ and $\mathrm{N}(1)-\mathrm{H}(1 \mathrm{~A}) \cdots \pi$ interactions from the quinonoid ring are transparent. On the other hand the $\mathrm{C}(12)-\mathrm{H}(12 \mathrm{~B}) \cdots \pi$ interactions bring forth the binding with benzenoid moiety as can be deciphered from Fig. 10. Subsequently the interactions between asymmetric molecules engender marginal variations in their corresponding proton distances.

\section{Sensing metal ion binding of $\mathrm{H}-1$ and $\mathrm{H}-3$}

No significant colour change was observed in metal ions binding studies experiments of $\mathbf{H}-\mathbf{2}$ and $\mathbf{H}-\mathbf{4}$. The metal ion binding studies thus focuses on $\mathbf{H - 1}$ and $\mathbf{H}-\mathbf{3}$ ligands. Metal ion

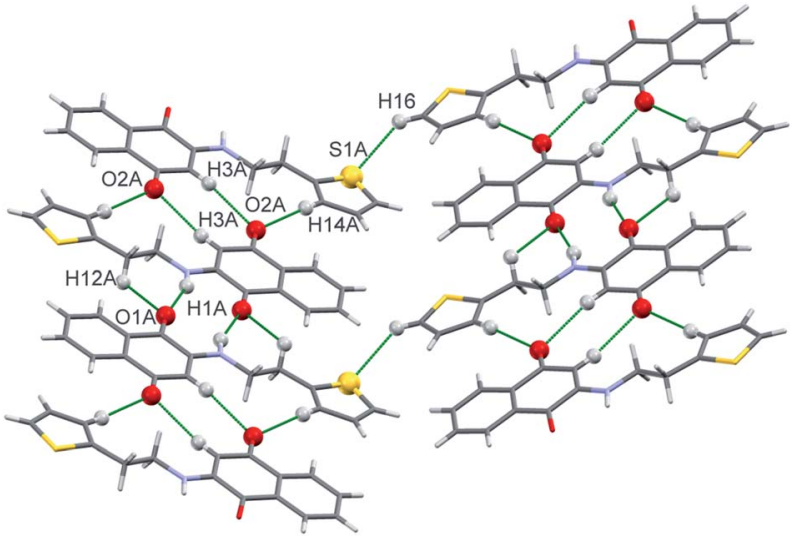

Fig. 9 Figure showing two asymmetric molecules of $\mathrm{H}-4$ are joined by $\mathrm{C}-\mathrm{H} \cdots \mathrm{S}$ interaction.

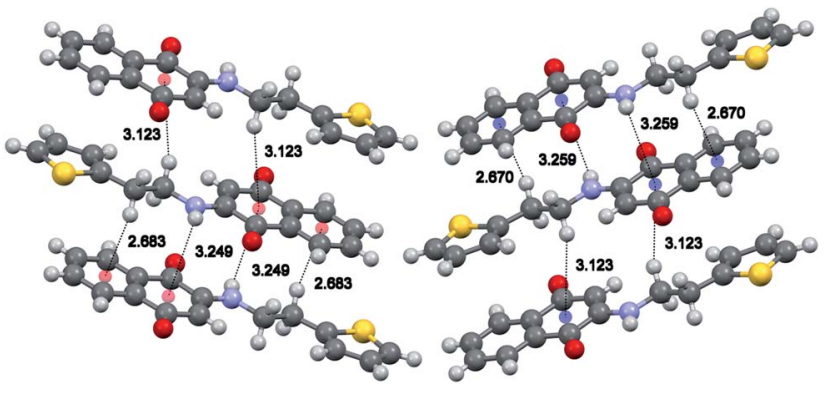

Fig. $10 \mathrm{C}-\mathrm{H} \cdots \pi$ and $\mathrm{N}-\mathrm{H} \cdots \pi$ interaction of $\mathrm{H}-4$ molecules.

binding studies ${ }^{35}$ were carried out (i) in methanol (ii) in methanol-water, (iii) in presence of mild base triethylamine (TEA) in (i) and (ii) conditions. TEA was used for deprotonation of ligand for detection of metal ions.

Equal volumes of $\left(2.5 \times 10^{-4} \mathrm{M}\right)$ of different metal ion solutions were mixed with $\mathbf{H}-\mathbf{1}$ and $\mathbf{H}-\mathbf{3}$ in methanol at room temperature $\left(26^{\circ} \mathrm{C}\right)$. A color change from orange in $\mathbf{H}-\mathbf{1}$ on addition of $\mathrm{Cu}^{2+}, \mathrm{Cu}^{+}, \mathrm{Ni}^{2+}, \mathrm{Zn}^{2+}$ and $\mathrm{Co}^{2+}$ ions can be attributed to deprotonation of $\mathrm{N}-\mathrm{H}$ of the ligand which can be visualized with the naked eye (Fig. 11). A new band appeared in the range of 500-700 nm for $\mathrm{Zn}^{2+}, \mathrm{Cu}^{2+}, \mathrm{Cu}^{+}, \mathrm{Ni}^{2+}$ and $\mathrm{Co}^{2+}$ in the UVvisible spectra portrayed in Fig. 13a. The addition of triethylamine prior to addition of the metal ion solution, show a color change in the $\mathbf{H - 1}$ (shown in Fig. 11b) only for $\mathrm{Zn}^{2+}, \mathrm{Cu}^{2+}, \mathrm{Cu}^{+}$, $\mathrm{Ni}^{2+}$ and $\mathrm{Co}^{2+}$ which is accompanied by an emergence of a new band in $\sim 500-700 \mathrm{~nm}$ region (Fig. 13b).

Interestingly $\mathbf{H}-3$ only shows color change with $\mathrm{Cu}^{+}$and $\mathrm{Cu}^{2+}$ in methanol as can readily be noticed from Fig. 12a, subsequent addition of triethylamine led to binding with $\mathrm{Cu}^{+}, \mathrm{Cu}^{2+}, \mathrm{Ni}^{2+}$ and $\mathrm{Co}^{2+}$ ions concomitantly bringing about the color change for H-3 as evident from Fig. 12b (and also Fig. S9 shown in $\mathrm{ESI}_{\dagger} \dagger$ ).

Fig. 11c displays $\mathbf{H - 1}$ in the 1 : 1 mixture of methanol-water. Here the color change from yellow to grey was noticed only for the $\mathrm{Cu}^{2+}$. No color change was observed for the rest of the metal ions studied. In other words, $\mathbf{H - 1}$ selectively detects $\mathrm{Cu}^{2+}$ ion in methanol-water solvent mixture with the naked eye. Similar inferences are drawn for the H-3 ligand shown in Fig. 12c.

As inferred from Fig. 11d and 12d; H-1 and H-3 do not show any noticeable color change for triethylamine and methanolwater solvent mixtures. On addition of $\mathrm{Ni}^{2+}$ and $\mathrm{Zn}^{2+}$ solution the UV-visible spectra emerge with new bands near $\lambda_{\max } 340 \mathrm{~nm}$ and $360 \mathrm{~nm}$ displayed in Fig. 13d and Fig. S9d in ESI. $\dagger$

\section{Competitive binding, pH dependent binding studies and detection limit of $\mathrm{H}-1$ and $\mathrm{H}-3$}

The stoichiometry of H-1 (Fig. S10 through Fig. S12 in ESI $\dagger$ ) and H-3 (Fig. S14 through Fig. S16 in ESI $\dagger$ ) for $\mathrm{Cu}^{2+}, \mathrm{Ni}^{2+}$ was determined by the Job's plot method. As illustrated $\mathbf{H}-\mathbf{1}$ with $\mathrm{Cu}^{2+}$ showed 1:1 stoichiometry in methanol as well as methanol-water mixtures, whereas the $2: 1$ stoichiometry was suggested for the $\mathrm{Ni}^{2+}$ in methanol (Fig. S10 in ESI $\dagger$ ). Besides $\mathrm{Cu}^{2+}$ in methanol-water-triethylamine mixture (Fig. S11 in ESI $\dagger$ ) revealed 2 : 1 stoichiometry. Likewise the $\mathbf{H}-3$ on combining with 
a)

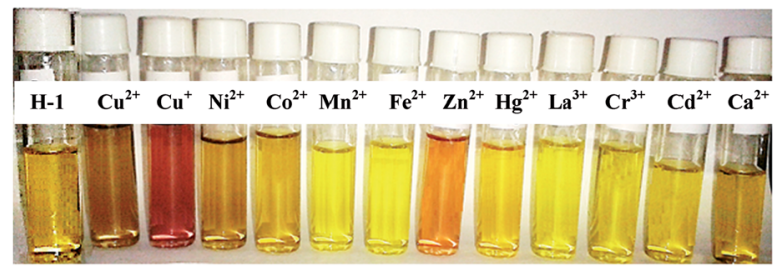

b)

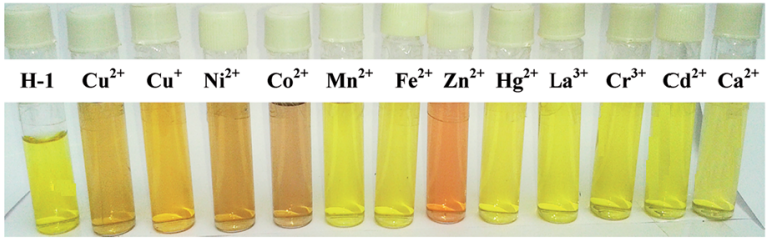

c)

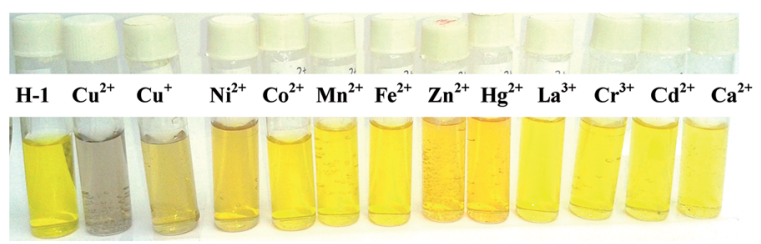

d)

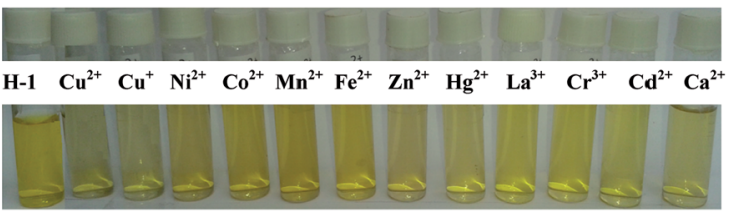

Fig. 11 (a) Color changes observed to chemosensor H-1 $\left(2.5 \times 10^{-4}\right.$ M) with metal ions $\left(2.5 \times 10^{-4} \mathrm{M}\right)$ in methanol. (b) Color changes observed to chemosensor $\mathrm{H}-1\left(2.5 \times 10^{-4} \mathrm{M}\right)$ with metal ions $(2.5 \times$ $10^{-4} \mathrm{M}$ ) in methanol-triethylamine. (c) Color changes observed to chemosensor $\mathrm{H}-1\left(2.5 \times 10^{-4} \mathrm{M}\right)$ with metal ions $\left(2.5 \times 10^{-4} \mathrm{M}\right)$ in methanol-water media. (d) Color changes observed to chemosensor $\mathrm{H}-1\left(2.5 \times 10^{-4} \mathrm{M}\right)$ with metal ions $\left(2.5 \times 10^{-4} \mathrm{M}\right)$ in methanol-triethylamine-water.

$\mathrm{Cu}^{2+}$ in methanol, methanol-triethylamine and methanol-water solvent mixture the stoichiometry was shown to be in 1:1 proportions. H-1 and $\mathbf{H}-\mathbf{3}$ ligands coordinating in tridentate manner with two nitrogen and a quinonoid oxygen bound to metal ions. The tetrahedral $1: 1$ complex $\mathrm{Cu}^{2+}$ and $1: 2$ octahedral complex of $\mathrm{Ni}^{2+}$ was proposed for such type of ligands. ${ }^{\mathbf{4 0 , 4 1}}$

Association constant of $\mathrm{Cu}^{2+}$ ion was determined using the Stern-Volmer plots from fluorescence experiments (Fig. S13 (for H-1) and Fig. S17 (for H-3) in ESI $\dagger$ ). The concentrations of $\mathbf{H - 1}$ or H-3 used were $5 \times 10^{-4} \mathrm{M}$ and that for the metal being $1 \times$ $10^{-3} \mathrm{M}$. The methanol solutions were used. The association constants $\left(K_{\mathrm{a}}\right)$ for $\mathbf{H}-\mathbf{1}$ turned out to be $4932 \mathrm{M}^{-1}$ for $\mathrm{Cu}^{2+}$ whereas that for the $\mathrm{Ni}^{2+}$ was $1542 \mathrm{M}^{-1}$ (Fig. S13a and b in ESI $\dagger$ ). Likewise the association constants $\left(K_{\mathrm{a}}\right)$ for $\mathbf{H}-\mathbf{3}$ were observed to be $938.9 \mathrm{M}^{-1}$ and $790.7 \mathrm{M}^{-1}$ respectively, for $\mathrm{Cu}^{2+}$ and $\mathrm{Ni}^{2+}$.

A competitive binding of metal ions was further studied through experiments in which equal volumes of $\mathbf{H}-\mathbf{1}$ and $\mathbf{H}-\mathbf{3}$ a)

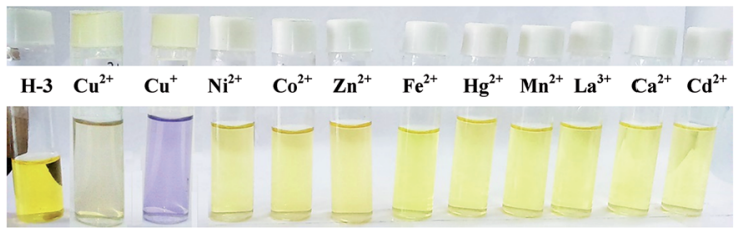

b)

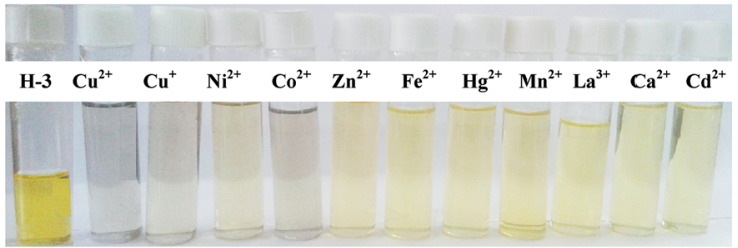

c)

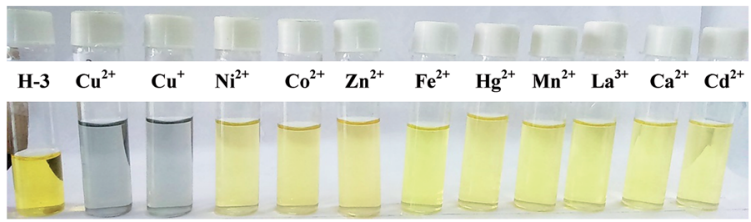

d)

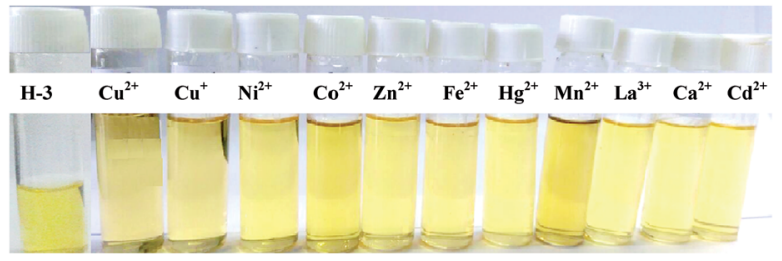

Fig. 12 (a) Color changes observed to chemosensor $\mathrm{H}-3\left(2.5 \times 10^{-4}\right.$ M) with metal ions $\left(2.5 \times 10^{-4} \mathrm{M}\right)$ in methanol. (b) Color changes observed to chemosensor $\mathrm{H}-3\left(2.5 \times 10^{-4} \mathrm{M}\right)$ with metal ions $(2.5 \times$ $\left.10^{-4} \mathrm{M}\right)$ in methanol-triethylamine. (c) Color changes observed to chemosensor $\mathrm{H}-3\left(2.5 \times 10^{-4} \mathrm{M}\right)$ with metal ions $\left(2.5 \times 10^{-4} \mathrm{M}\right)$ in methanol-water. (d) Color changes observed to chemosensor $\mathrm{H}-3$ $\left(2.5 \times 10^{-4} \mathrm{M}\right)$ with metal ions $\left(2.5 \times 10^{-4} \mathrm{M}\right)$ in methanol-triethylamine-water.

$\left(1 \times 10^{-4} \mathrm{M}\right)$ were mixed with those of $\mathrm{Cu}^{2+}, \mathrm{Ni}^{2+}$ and $\mathrm{Co}^{2+}$ $\left(1 \times 10^{-3} \mathrm{M}\right)$. Noticeable colour changes can be noticed in solution mixture of metal ions (Fig. 14 and S18 in ESI $\dagger$ ) for $\mathbf{H - 1}$ and H-3. UV-visible (Fig. S19 in ESI $\dagger$ ) and fluorescence spectra of selected metal ion are displayed in Fig. 15. Ligands $\mathbf{H - 1}$ and $\mathbf{H}-\mathbf{3}$ are fluorescent and showed low quantum yields of $0.99 \%$ and $1.89 \%$, respectively. Noteworthy enough, $\mathrm{Cu}^{2+}$ demonstrate significant fluorescence quenching for $\mathbf{H}-\mathbf{1}$ and $\mathbf{H}-\mathbf{3}$. The experiments further showed $\mathrm{Ni}^{2+}$ and $\mathrm{Co}^{2+}$ bring about competitive binding to $\mathbf{H - 1}$ and $\mathbf{H}-3$ however $\mathrm{Cu}^{2+}$ prevailing over other metal ions which is in accordance with its large binding constant.

$\mathrm{pH}$ dependent metal ion binding experiments of $\mathbf{H}-\mathbf{1}$ and $\mathbf{H}-\mathbf{3}$ were carried out on metal ions $\mathrm{Zn}^{2+}, \mathrm{Cu}^{2+}, \mathrm{Ni}^{2+}$ and $\mathrm{Co}^{2+}$ in buffer solution of $\mathrm{pH} 4,7$ and 9. The metal ion binding was observed only in the basic pH (Fig. S20 in ESI $\dagger$ ) and not for $\mathrm{pH}=4$.

The limit of detection (LOD) from the fluorescence experiments ${ }^{\mathbf{4 2 , 4 3}}$ with $\mathrm{Cu}^{2+}$ and $\mathbf{H - 1}$ or $\mathbf{H - 3}$ ligands are observed to be $1.48 \times 10^{-8} \mathrm{~mol} \mathrm{~L}^{-1}$ for $\mathbf{H}-1$ (Fig. S21 in ESI $\dagger$ ) and $1.59 \times$ $10^{-8} \mathrm{~mol} \mathrm{~L}^{-1}$ (Fig. S22 in ESI $\dagger$ ) for $\mathbf{H}-3$. 
a)

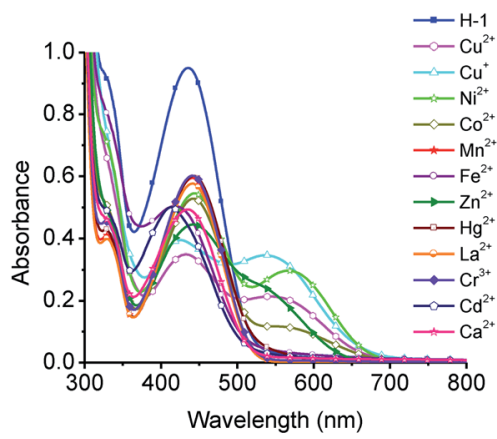

c)

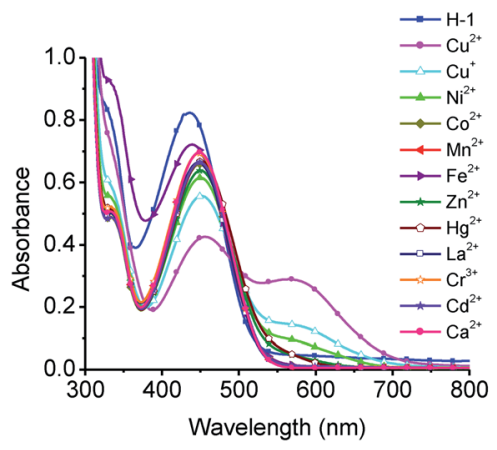

b)

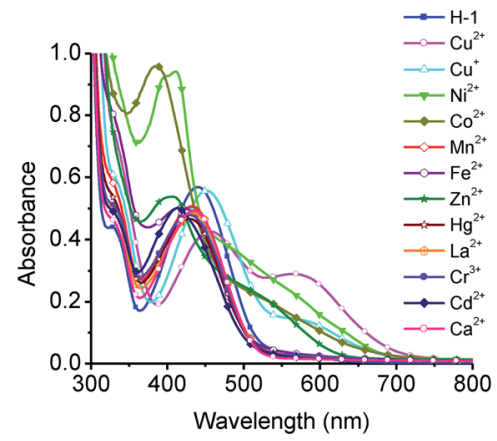

d)

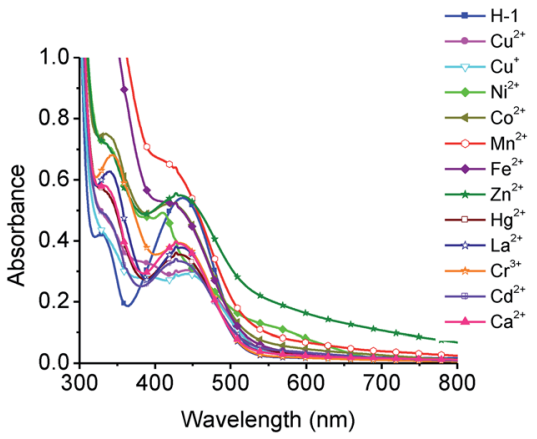

Fig. 13 (a) UV-visible spectra of $\mathrm{H}-1$ in presence of various metal ions in methanol. (b) UV-visible spectra of $\mathrm{H}-1$ in presence of various metal ions in methanol-triethylamine. (c) UV-visible spectra of $\mathrm{H}-1$ in presence of various metal ions in methanol : water media. (d) UV-visual spectra of $\mathrm{H}-1$ in presence of various metal ions in methanol-TEA-water.

\section{DFT investigations}

Optimized structures of aminonaphthoquinone derivatives obtained from the M06-2X based density functional theory are depicted in Fig. 16. Selected bond distances and angles are compared with X-ray crystal data in Table 3. As shown the overall structural parameters agree well with the experiments. A comparison of $\mathbf{H - 1}$ and $\mathbf{H}-\mathbf{2}$ shows that carbonyl $\mathrm{C}(1) \mathrm{O}(1)$ bond distances are marginally elongated on substitution of thiophene instead of pyridine.

Structural ramifications in vibration frequencies are analyzed. Calculated vibrational frequencies of $\mathbf{H}-\mathbf{1}, \mathbf{H}-\mathbf{2}, \mathbf{H}-\mathbf{3}$ and $\mathbf{H}-\mathbf{4}$ are compared with the experiment in Table 4 . As may be inferred the $\mathrm{N}-\mathrm{H}$ stretching assigned to $3247 \mathrm{~cm}^{-1}$ of $\mathbf{H - 1}$ engenders the frequency up shift of $\sim 42 \mathrm{~cm}^{-1}$ for the ethyl substituted H-3. As oppose to this in case of thiophene on substitution of the ethyl functionality engender the lowering of

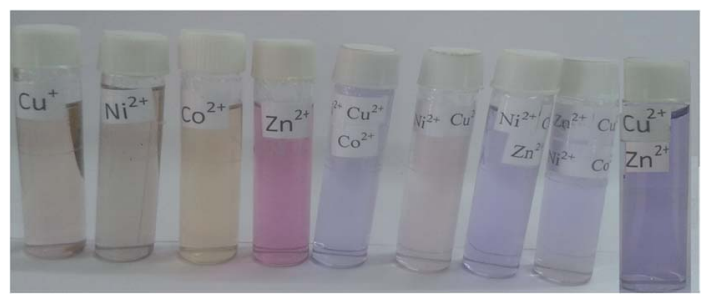

Fig. 14 Color changes observed to $\mathrm{H}-1$ and metal ions $\left(1 \times 10^{-4} \mathrm{M}\right)$ in methanol.

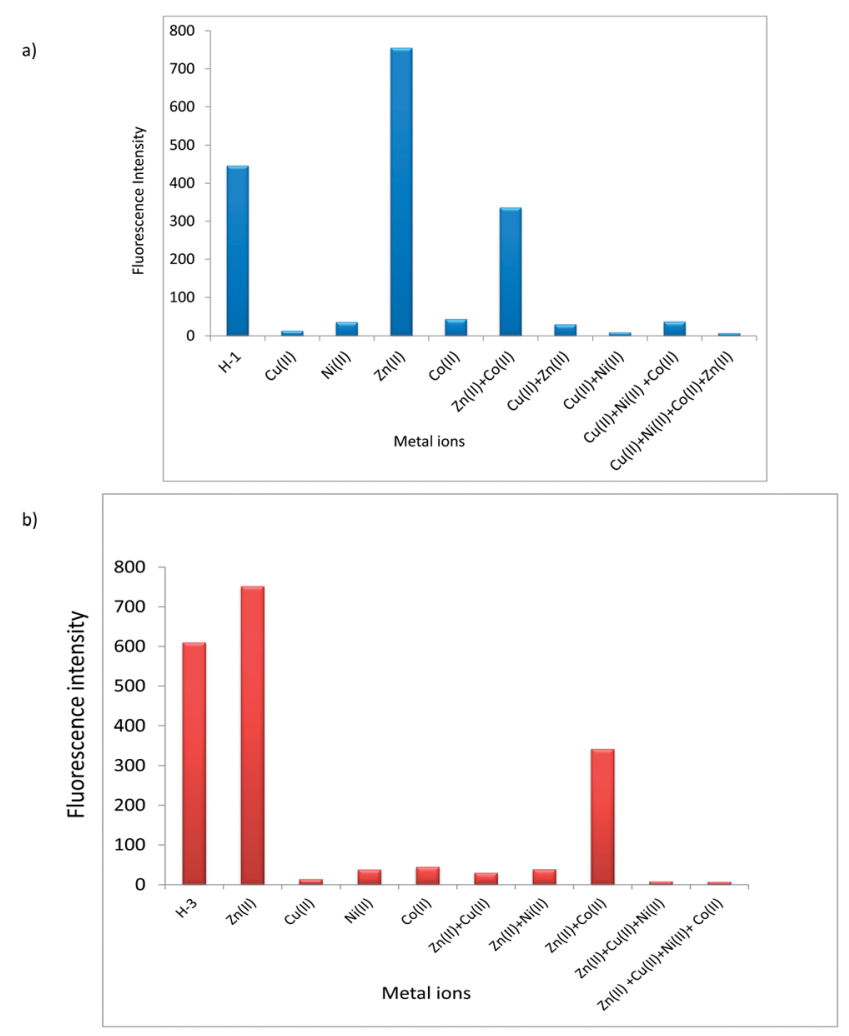

Fig. 15 (a) Fluorescence spectra of competitive binding of metal ions with chemosensor $\mathrm{H}-1$. (b) Fluorescence spectra of competitive binding of metal ions with chemosensor $\mathrm{H}-3$. 
a)

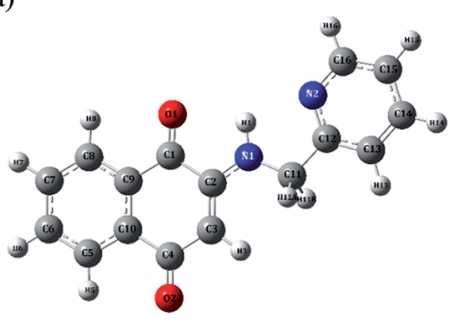

c)

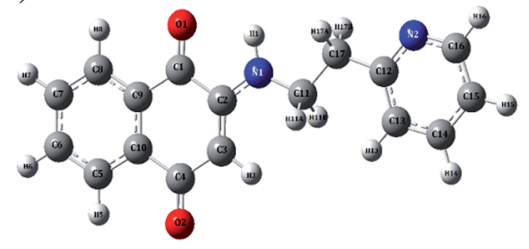

b)

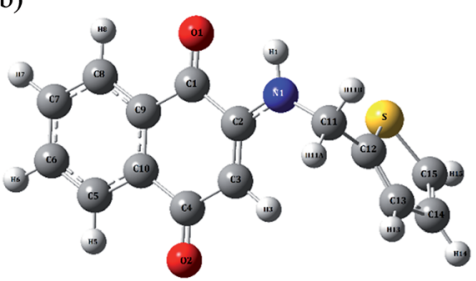

d)

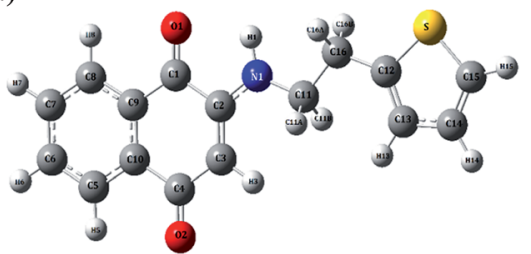

Fig. 16 Optimized geometries of (a) $\mathrm{H}-1$, (b) $\mathrm{H}-2$, (c) $\mathrm{H}-3$ and (d) $\mathrm{H}-4$.

Table 3 Selected bond distances (in Å) in $\mathrm{H}-1, \mathrm{H}-2, \mathrm{H}-3$ and $\mathrm{H}-4$

\begin{tabular}{|c|c|c|c|c|c|c|}
\hline & \multicolumn{2}{|l|}{ H-1 } & \multicolumn{2}{|l|}{ H-3 } & \multicolumn{2}{|l|}{ H-4 } \\
\hline & Theo. & Obs. & Theo. & Obs. & Theo. & Obs. \\
\hline $\mathrm{C}=\mathrm{O}_{1}$ & 1.209 & 1.219 & 1.210 & 1.220 & 1.211 & 1.219 \\
\hline $\mathrm{C}=\mathrm{O}_{2}$ & 1.217 & 1.234 & 1.216 & 1.237 & 1.216 & 1.246 \\
\hline C3-H3 & 1.083 & 0.950 & 1.083 & 0.950 & 1.083 & 0.950 \\
\hline N1-H1 & 1.015 & 0.880 & 1.012 & 0.880 & 1.012 & 0.880 \\
\hline
\end{tabular}

Table 4 Selected vibrational frequencies in $\mathrm{cm}^{-1}(\nu)$ of $\mathrm{H}-1$ to $\mathrm{H}-4$ scaled by factor 0.91

\begin{tabular}{|c|c|c|c|c|c|c|c|c|}
\hline & \multicolumn{2}{|l|}{ H-1 } & \multicolumn{2}{|l|}{ H-2 } & \multicolumn{2}{|l|}{$\mathbf{H}-3$} & \multicolumn{2}{|l|}{ H-4 } \\
\hline & Theo. & Obs. & Theo. & Obs. & Theo. & Obs. & Theo. & $\mathrm{Ob}$ \\
\hline $\mathrm{N} 1-\mathrm{H} 1)$ & 3247 & 3355 & 3311 & 3354 & 3289 & 3336 & 3285 & 33 \\
\hline$\nu(\mathrm{C} 3-\mathrm{H} 3)$ & 2936 & 3061 & 2926 & 3061 & 2921 & 2960 & 2911 & 29 \\
\hline$\nu\left(\mathrm{C}=\mathrm{O}_{1}\right)$ & 1650 & 1672 & 1645 & 1670 & 1649 & 1672 & 1645 & 166 \\
\hline$\nu\left(\mathrm{C}=\mathrm{O}_{2}\right)$ & 1610 & 1632 & 1620 & - & 1617 & 1600 & 1618 & - \\
\hline$\nu(\mathrm{C}=\mathrm{C})$ & 1541 & 1593 & 1541 & 1599 & 1539 & 1570 & 1538 & 15 \\
\hline
\end{tabular}

Table $5{ }^{1} \mathrm{H}$ chemical shift (in ppm) in solvent and observed ${ }^{1} \mathrm{H}$ chemical shifts

\begin{tabular}{|c|c|c|c|c|c|c|c|c|}
\hline & \multicolumn{2}{|l|}{ H-1 } & \multicolumn{2}{|l|}{ H-2 } & \multicolumn{2}{|l|}{ H-3 } & \multicolumn{2}{|l|}{ H-4 } \\
\hline & Theo. & Obs. & Theo. & Obs. & Theo. & Obs. & Theo. & Obs. \\
\hline H1 & 8.1 & 8.08 & 6.5 & 8.11 & 5.6 & 7.62 & 5.6 & 7.55 \\
\hline H3 & 6.2 & 5.59 & 6.1 & 5.74 & 6.2 & 5.71 & 6.2 & 5.72 \\
\hline H5 & 8.4 & 7.90 & 9.0 & 7.90 & 8.4 & 7.92 & 8.4 & 7.33 \\
\hline H6 & 9.0 & 7.81 & 8.6 & 7.80 & 9.0 & 7.81 & 8.9 & 7.72 \\
\hline $\mathrm{H} 7$ & 8.6 & 7.77 & 8.5 & 7.71 & 9.0 & 7.70 & 9.1 & 7.82 \\
\hline H8 & 9.4 & 8.00 & 9.1 & 7.97 & 9.3 & 7.95 & 9.3 & 7.93 \\
\hline H11 & 4.6 & 4.52 & 4.9 & 4.61 & 3.6 & 3.54 & 3.6 & 3.45 \\
\hline H13 & 8.3 & 7.37 & 7.7 & 7.10 & 7.7 & 7.32 & 7.3 & 6.94 \\
\hline H14 & 8.5 & 7.73 & 7.7 & 6.97 & 8.5 & 7.72 & 7.6 & 6.96 \\
\hline H15 & 8.0 & 7.30 & 8.1 & 7.40 & 8.1 & 7.23 & 8.2 & 7.97 \\
\hline H16 & 9.7 & 8.55 & & & 9.6 & 8.51 & 3.4 & 3.12 \\
\hline H17 & & & & & 3.6 & 3.04 & & \\
\hline
\end{tabular}

frequency from $3311 \mathrm{~cm}^{-1}(\mathbf{H}-2)$ to $3285 \mathrm{~cm}^{-1}$ (H-4). The inferences borne out from DFT are thus in consonance with the experiment.

${ }^{1} \mathrm{H}-\mathrm{NMR}$ chemical shifts $\left(\delta_{\mathrm{H}}\right)$ in $\mathbf{H}-\mathbf{1}, \mathbf{H}-\mathbf{2}, \mathbf{H}-\mathbf{3}$ and $\mathbf{H}-\mathbf{4}$ in DMSO (as solvent) were simulated through the SCRF-PCM theory. A comparison with the experiment is given in Table 5 . The $\mathrm{H}(1)$ proton participating in $\mathrm{N}-\mathrm{H} \cdots \mathrm{O}$ and $\mathrm{N}-\mathrm{H} \cdots \mathrm{N}$ interactions in $\mathbf{H - 1}$ emerge with relatively large deshielding (8.1 $\mathrm{ppm}$ ) in the spectra. The signals of the corresponding proton in the rest of aminonaphthoquinone derivatives facilitate the $\mathrm{N}-\mathrm{H} \cdots \mathrm{O}$ interactions and appear at $\sim 6.5 \mathrm{ppm}$. The alkyl protons emerge with up-field $\delta_{\mathrm{H}}$ signals in the calculated ${ }^{1} \mathrm{H}$ NMR. These inferences on the calculated $\delta_{\mathrm{H}}$ values concur with the experiment.

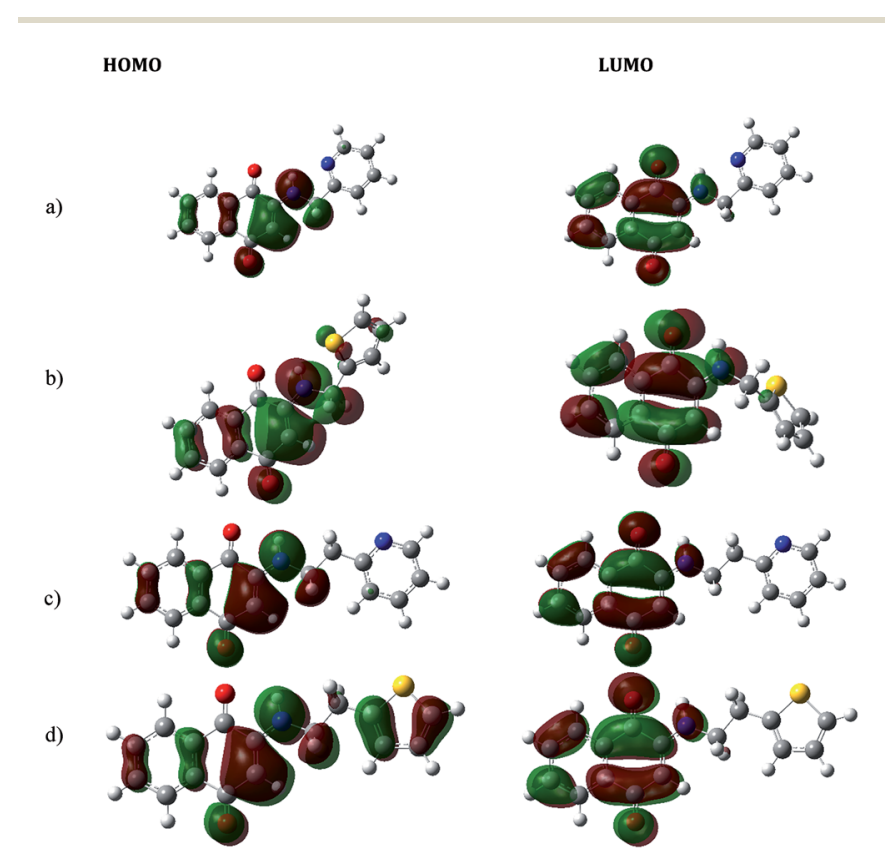

Fig. 17 Fronteir molecular orbitals of (a) $\mathrm{H}-1$, (b) $\mathrm{H}-2$, (c) $\mathrm{H}-3$ and (d) $\mathrm{H}-4$. 
Table $6 \mathrm{HOMO}$, LUMO gap (in eV) and global indices in $\mathrm{H}-1, \mathrm{H}-2, \mathrm{H}-3$ and $\mathrm{H}-4$

\begin{tabular}{lllll}
\hline Molecular properties & H-1 & H-2 & H-3 & H-4 \\
$\Delta E_{\text {HOMO-LUMO }}$ & 5.6 & 5.6 & 5.7 & 5.6 \\
Global hardness $(\eta)$ & 2.8 & 2.8 & 2.9 & 2.8 \\
Electronic chemical potential $(\mu)$ & 4.7 & 4.9 & 4.9 & 4.9 \\
Electronegativity $(\chi)$ & 4.7 & 4.9 & 4.9 & 4.9 \\
Global electrophilicity index $(\omega)$ & 4.0 & 4.3 & 4.3 & 4.3
\end{tabular}

The molecular Frontier orbital's HOMO and LUMO (isosurface of $\pm 0.04 \mathrm{au}$ ) in aminonaphthoquinone ligands are portrayed in Fig. 17. The complimentarily of charge distributions between HOMO and LUMO is thus transparent. The electronic absorption spectra except $\mathbf{H}-\mathbf{4}$ revealed the band near $\sim 336 \mathrm{~nm}$ assigned to the HOMO to LUMO transition. The HOMO-LUMO energies, global indices of reactivity, namely, chemical potential $(\mu)$, hardness $(\eta)$, and electrophillicity index $(\omega)$, are summarized in Table 6.

\section{Conclusions}

Naphthoquinone based chemosensors are characterized from the X-ray diffraction and spectroscopy experiments in conjunction with the density functional theory. X-ray diffraction experiments revealed the $\mathrm{C}-\mathrm{H} \cdots \pi$ interactions in molecular packing those bring about a variation in their optical properties. The metal ion binding of $\mathbf{H - 1}$ and $\mathbf{H - 3}$ in methanol, methanolwater mixture and in the presence of mild base triethylamine were examined. The binding of $\mathbf{H}-\mathbf{1}$ and $\mathbf{H}-3$ with $\mathrm{Cu}^{2+}$ revealed $1: 1$ stoichiometry in methanol water mixture compared to that of $\mathrm{Ni}^{2+}$ which was $1: 2$ proportions when the methanol or methanol-triethylamine mixture were used. The association constant of $\mathrm{Cu}^{2+}$ with $\mathbf{H}-\mathbf{1}$ was observed to be $\sim 5.2$ times as larger than that for the H-3. Secondly, the ligands $\mathbf{H}-\mathbf{1}$ and $\mathbf{H}-\mathbf{3}$ display remarkable recognition ability toward the $\mathrm{Cu}^{2+}, \mathrm{Ni}^{2+}$, $\mathrm{Co}^{2+}$ ions in methanol. Both ligands showed remarkable selectivity in the detection of $\mathrm{Cu}^{2+}$ in methanol/ $\mathrm{H}_{2} \mathrm{O}$ solution. The experimental investigations further were corroborated through the inferences drawn based on the ${ }^{1} \mathrm{H}$ NMR and infrared spectra derived from the density functional theory.

\section{Conflicts of interest}

There are no conflicts to declare.

\section{Acknowledgements}

SSG and SS grateful to DST-SERB (EMR/2016/007912). SPG acknowledges support from the Research Project (37(2)/14/11/ 2015-BRNS) from the Board of Research in Nuclear Sciences (BRNS), India. PM, AP and DNL thankful to Savitribai Phule Pune University for the award of research fellowship through the University of Potential excellence scheme from the University Grants Commission, New Delhi, India. SPG thanks Centre for Development of Advanced Computing (C-DAC), Pune for computer time on National Param Supercomputing Facility.

\section{References}

1 L. Li, E. Leyva and R. Las Garcia, Rev. Mex. Cienc. Farm., 2011, 42, 6-17.

2 R. P. Varma, Med. Chem., 2006, 6, 489-499.

3 H. R. Lawrence, A. Kazi, Y. Luo, R. Kendig, Y. Ge, S. Jain, K. Daniel, D. Santiago, W. C. Guida and S. M. Sebti, Bioorg. Med. Chem., 2007, 18, 5576-5592.

4 V. K. Tandon, H. K. Maurya, A. Tripathi, G. B. Shivakeshava, P. V. Shukla, P. Srivastava and D. Panda, Eur. J. Med. Chem., 2009, 44, 1088-1092.

5 E. H. da Cruz, C. M. Hussene, G. G. Dias, E. B. Diogo, I. M. de Melo, B. L. Rodrigues, M. G. da Goukrt, B. C. Cavalcanti, C. Pessoa and E. N. da Silva Junior, Bioorg. Med. Chem., 2014, 22, 1609-1619.

6 H. R. Nasiri, M. G. Madej, R. Panisch, M. Lafontaine, J. W. Bats, C. R. Lancaster and H. Schwalbe, J. Med. Chem., 2013, 56, 9530-9541.

7 D. Bhasin, S. N. Chettiar, J. P. Etter, M. Mok and P. K. Li, Bioorg. Med. Chem., 2013, 21, 4662-4669.

8 C. V. Ryu and D. H. Kim, Arch. Pharmacal Res., 1992, 15, $263-$ 268.

9 V. K. Tandon, H. K. Maurya, N. N. Mishra and P. K. Shukla, Eur. J. Med. Chem., 2009, 44, 3130-3137.

10 J. J. Inbaraj and C. F. Chignell, Chem. Res. Toxicol., 2004, 17, 55-62.

11 V. K. Tandon, R. B. Chhor, R. V. Singh, S. Raj and D. B. Yadav, Bioorg. Med. Chem. Lett., 2004, 14, 1079-1083.

12 K. Sasaki, H. Abe and F. Yoshizaki, Biol. Pharm. Bull.l, 2002, 25, 669-670.

13 V. K. Tandon, D. B. Yadav, H. K. Maurya, A. K. Chaturvedi and P. K. Shukla, Bioorg. Med. Chem., 2006, 14, 6120-6126.

14 T. Kayashima, M. Mori, H. Yoshida, Y. Mizushina and K. Matsubara, Cancer Lett., 2009, 278, 34-40.

15 E. N. Da Silva Jr, D. F. de Deus, B. C. Cavalcanti, C. Pessoa, L. V. Costa-Lotufo, R. C. Motenegro, M. O. de Moraes, M. C. E. R. Pinto, C. A. de Simone, V. F. Fereira, M. O. F. Goulart, C. K. Z. Andrade and A. V. Pinto, J. Med. Chem., 2010, 53, 504-508.

16 O. D. Zakharova, L. P. Ovchinnikova, L. I. Goryunov, N. M. Troshkova, V. D. Shteingarts and G. A. Nevinsky, Eur. J. Med. Chem., 2010, 45, 2321-2326.

17 J. Benites, J. A. Valderrama, K. Bettega, R. C. Pedrosa, P. B. Calderon and J. Verrax, Eur. J. Med. Chem., 2010, 45, 6052-6057.

18 N. Pradidphol, N. Kongakathip, P. Sittikul, N. Boonyalai and B. Kongkathip, Eur. J. Med. Chem., 2012, 49, 253-270.

19 V. K. Tandon, R. V. Singh, S. Raj, R. B. Chhor and Z. K. Khan, Boll. Chim. Farm., 2002, 141, 304-310.

20 T. V. Ilina, E. A. Semenova, T. R. Pronvaeva, A. G. Pokrovskii, I. N. Nechepurenko, E. E. Shults, O. I. Anderrva, S. N. Kochetkov and G. A. Tolstikov, Dokl. Biochem. Biophys., 2002, 382, 56-59.

21 A. J. M. da Silva, C. D. Buarque, F. V. Brito, L. Aurelian, L. F. Macedo, L. H. Malkas, R. J. Hickey, D. V. S. Lopes, Y. L. B. Murakami, N. M. V. Silva, P. A. Melo, 
R. R. B. Laruso, N. G. Castro and P. R. R. Costa, Bioorg. Med. Chem., 2002, 10, 2731-2738.

22 E. N. da Silva, M. Cecillia, B. V. de Souza, A. V. Pinto, F. R. Pinto, M. O. F. Goulart, F. W. A. Barros, C. Pessoa, L. V. Costa-Lotufa, R. C. Montenegro, M. Moraesel and V. F. Ferreiraa, Bioorg. Med. Chem., 2007, 15, 7035-7042.

23 M. A. Maetinez, G. Uevas, M. J. Estrada, I. Gonzalez, B. L. Hennasen and N. M. Ruvalcaba, J. Org. Chem., 1999, 64, 3684-3694.

24 (a) Z. Xu, Y. Xiao, X. Qian, J. Cui and D. Cui, Org. Lett., 2005, 7, 889-892; (b) Y. Kubo, M. Ymamoto, M. Ikeda, M. Takeuchi, S. Shinkai, S. Yamaguchi and K. Tamao, Angew. Chem., Int. Ed., 2003, 42, 2036-2040.

25 D. D. Perrin, W. L. Armarego and D. R. Perrin, Purification of Laboratory Chemicals, Pergamon Press, London, 1988, p. 260.

26 Bruker, APEX2, SAINT and SADABS, Bruker AXS Inc, Madison, Wisconsin, USA, 2007.

27 G. M. Sheldrick, Acta Crystallogr., Sect. A: Found. Crystallogr., 2008, 64, 112-122.

28 L. J. Farrugia, J. Appl. Crystallogr., 2012, 45, 849-854.

29 C. F. Macrae, I. J. Bruno, J. A. Chisholm, P. R. Edgington, P. McCabe, E. Pidcock, L. Rodriguez-Monge, R. Taylor, J. Van de Streek and P. A. Wood, J. Appl. Crystallogr., 2008, 41, 466-470.

30 L. R. Monge, R. Taylor, J. van de Streek and P. A. Wood, J. Appl. Crystallogr., 2008, 41, 466-470.

31 L. Spek, Acta Crystallogr., Sect. D: Biol. Crystallogr., 2009, 65, 148-155.

32 M. J. Frisch, G. W. Trucks, H. B. Schlegel, G. E. Scuseria, M. A. Robb, J. R. Cheeseman, J. A. Montgomery Jr, T. Vreven, K. N. Kudin, J. C. Burant, J. M. Millam, S. S. Iyengar, J. Tomasi, V. Barone, B. Mennucci, M. Cossi, G. Scalmani, N. Rega, G. A. Petersson, H. Nakatsuji, M. Hada, M. Ehara, K. Toyota, R. Fukuda, J. Hasegawa, M. Ishida, T. Akajima, Y. Honda, O. Kitao, H. Nakai, M. Klene, X. Li, J. E. Knox, H. P. Hratchian, J. B. Cross, V. Bakken, C. Adamo, J. Jaramillo, R. Gomperts, R. E. Stratmann, O. Yazyev, A. J. Austin, R. Cammi,
C. Pomelli, J. W. Ochterski, P. Y. Ayala, K. Morokuma, G. A. Voth, P. Salvador, J. J. Dannenberg, V. G. Zakrzewski, S. Dapprich, A. D. Daniels, M. C. Strain, O. Farkas, D. K. Malick, A. D. Rabuck, K. Raghavachari, J. B. Foresman, J. V. Ortiz, Q. Cui, A. G. Baboul, S. Clifford, J. Cioslowski, B. B. Stefanov, G. Liu, A. Liashenko, P. Piskorz, I. Komaromi, R. L. Martin, D. J. Fox, T. Keith, M. A. Al-Laham, C. Y. Peng, A. Nanayakkara, M. Challacombe, P. M. W. Gill, B. Johnson, W. Chen, M. W. Wong, C. Gonzalez and J. A. Pople, Gaussiano3, revision, Gaussian, Inc., Pittsburgh, PA, 2003.

33 R. Patil, D. Chadar, D. Chaudhari, J. Peter, M. Nikalje, T. Weyhermüller and S. Salunke-Gawali, J. Mol. Struct., 2014, 1075, 345-351.

34 S. Salunke-Gawali, L. Kathawate, Y. Shinde, V. G. Puranik and T. Weyhermüller, J. Mol. Struct., 2012, 1010, 38-45.

35 S. Salunke-Gawali, O. Pawar, M. Nikalje, R. Patil, T. Weyhermüller, V. G. Puranik and V. B. Konkimalla, J. Mol. Struct., 2014, 1056-1057, 97-103.

36 S. Salunke-Gawali, L. Kathawate and V. G. Puranik, J. Mol. Struct., 2012, 1022, 189-196.

37 S. Salunke-Gawali, S. Y. Rane, V. G. Puranik, C. GuyardDuhayan and F. Varret, Polyhedron, 2004, 23, 2541-2547.

38 S. Pal, M. Jadhav, T. Weyhermüller, Y. Patil, M. Nethaji, U. Kasabe, L. Kathawate, V. Badireenath Konkimalla and S. Salunke-Gawali, J. Mol. Struct., 2013, 1049, 355-361.

39 A. P. Ware, A. Patil, S. Khomane, T. Weyhermüller, S. S. Pingale and S. Salunke-Gawali, J. Mol. Struct., 2015, 1093, 39-48.

40 A. Patil, D. Lande, A. Nalkar, S. P. Gejji, D. Chakravarty, R. Gonnade, T. Moniz, M. Rangel, E. Periera and S. Salunke-Gawali, J. Mol. Struct., 2017, 1143, 495-514.

41 G. Agarwal, D. N. Lande, D. Chakravarty, S. P. Gejji, P. Gosavi-Mirkute, A. Patil and S. Salunke-Gawali, RSC Adv., 2016, 6, 88010-88029.

42 Q. Lin, T. Lu, X. Zhu, T. Wei, H. Li and Y. Zhang, Chem. Sci., 2016, 7, 5341-5346.

43 Q. Lin, P. Mao, Y. Fan, L. Liu, J. Liu, Y. Zhang, H. Yao and T. Wei, Soft Matter, 2017, 13, 7085-7089. 